\title{
A Pseudomonas syringae Diversity Survey Reveals a Differentiated Phylotype of the Pathovar syringae Associated with the Mango Host and Mangotoxin Production
}

\author{
José A. Gutiérrez-Barranquero, Víctor J. Carrión, Jesús Murillo, Eva Arrebola, Dawn L. Arnold, \\ Francisco M. Cazorla, and Antonio de Vicente
}

First, second, sixth, and seventh authors: Instituto de Hortofruticultura Subtropical y Mediterránea La Mayora (IHSM-UMA-CSIC), Departamento de Microbiología, Facultad de Ciencias, Universidad de Málaga, Spain; third author: Laboratorio de Patología Vegetal, ETS Ingenieros Agrónomos, Universidad Pública de Navarra, Pamplona, Spain; fourth author: IHSM-UMA-CSIC, Estación Experimental La Mayora, Algarrobo-Costa, Málaga, Spain; and fifth author: Department of Applied Sciences, University of the West of England, Bristol, UK.

Accepted for publication 22 May 2013.

\begin{abstract}
Gutiérrez-Barranquero, J. A., Carrión, V. J., Murillo, J., Arrebola, E., Arnold, D. L., Cazorla, F. M., and de Vicente, A. 2013. A Pseudomonas syringae diversity survey reveals a differentiated phylotype of the pathovar syringae associated with the mango host and mangotoxin production. Phytopathology 103:1115-1129.

Pseudomonas syringae pv. syringae, the causal agent of bacterial apical necrosis (BAN) in mango crops, has been isolated in different mango-producing areas worldwide. An extensive collection of $87 P$. syringae pv. syringae strains isolated from mango trees affected by BAN from different countries, but mainly from Southern Spain, were initially examined by repetitive sequence-based polymerase chain reaction (repPCR) to analyze the genetic diversity with an epidemiological aim. repPCR was powerful in assessing intrapathovar distribution and also allowing clustering of the $P$. syringae pv. syringae strains isolated from mango,

served for all the $P$. syringae pv. syringae strains isolated from mango distinct from strains from other hosts, including strains for the same geographical regions as the mango isolates. For this reason, a representative group of $51 P$. syringae pv. syringae strains isolated from mango and other hosts, as well as some $P$. syringae strains from other pathovars, were further characterized to determine their possible genetic, phenotypic, and phylogenetic relationships. Similar to the rep-PCR results, the randomly amplified polymorphic DNA PCR (RAPD-PCR) and catabolic diversity analysis using the Biolog GN2 profile grouped $90 \%$ of the mango isolates together in a unique cluster. Interestingly, the majority of $P$. syringae pv. syringae strains isolated from mango produced mangotoxin. The analysis of the phylogenetic distribution using the multilocus sequence typing analysis strongly supports the existence of a differentiated phylotype of the pathovar syringae mainly associated with the mango host and characterized by the mangotoxin production.
\end{abstract} depending on the isolation area. A clear pattern of clustering was ob-
Pseudomonas syringae is unique in its ability to cause diseases in a wide range of hosts, up to 180 plant species worldwide $(13,40)$. P. syringae is taxonomically subdivided into pathogenic varieties known as pathovars, based on the host of isolation (77). Pathovars of the $P$. syringae complex have traditionally been defined both biochemically and by pathogenicity tests. Schaad et al. (65) described biochemical-nutritional tests that differentiate between pathovars of this bacterial species. However, strains of $P$. syringae infecting unreported hosts and that are biochemically similar to $P$. syringae pv. syringae strains have been frequently placed into the pathovar syringae without establishment of a common host range (77).

The pathovar-based classification of the $P$. syringae complex has a practical interest but it does not reveal the genetic relationship among pathovars. Gardan et al. (26) described nine genomic species within $P$. syringae on the basis of DNA pairing analysis. Meanwhile, Clerc et al. (22) demonstrated that other genetic techniques such as randomly amplified polymorphic DNA (RAPD) and amplified fragment length polymorphism (AFLP)

Corresponding author: A. de Vicente; E-mail address: adevicente@uma.es

* The $e$-Xtra logo stands for "electronic extra" and indicates that the online version contains four supplemental tables and one supplemental figure.

http://dx.doi.org/10.1094/PHYTO-04-13-0093-R

(c) 2013 The American Phytopathological Society could be used as alternatives to DNA pairing studies and often agree with the classification obtained by polymerase chain reaction (PCR) restriction fragment length polymorphism of the $r r n$ operon (49), DNA pairing studies, and analysis of pathogenicity data. In addition to these studies, repetitive sequencebased PCR (rep-PCR) has been successfully used to demonstrate considerable genetic diversity among $P$. syringae pathovars (46, 69). This fingerprinting technique has been widely used in different pathovars of $P$. syringae, highlighting the possibility of its use to observe intraspecific or intrapathovar genetic diversity $(25,39,45,51,52)$. Additionally, multilocus sequence typing (MLST) could be considered as an alternative technique to characterize phylogenetic relationships of bacteria, by analysis of genes sequences that belong to the core genome $(37,48,63)$. Sarkar and Guttman (63) provided the first MLST analysis of this plantpathogenic bacterium, reporting that $P$. syringae is a highly clonal population. Later, MLST was demonstrated to be highly discriminative, accurately allocating $P$. syringae isolates to their corresponding genomospecies and revealing previously unknown diversity (14).

$P$. syringae pv. syringae is one of the 60 pathovars (77) belonging to the highly heterogeneous species $P$. syringae. Bacterial apical necrosis (BAN) of mango caused by $P$. syringae pv. syringae strains is the most limiting disease of mango crops in the Mediterranean area $(16,20)$, as well as in other subtropical areas, such as northwestern Australia (29). BAN disease significantly 
reduces the commercial viability of mango crops and, thus, several attempts have been made to control this disease $(16,30)$. Furthermore, a preliminary study of $P$. syringae pv. syringae strains isolated from mango revealed the existence of genetic diversity within this pathovar (31) that could be helpful for a future epidemiological study to determine the origin of the isolated pathogens and their distribution.

During the interaction of $P$. syringae with the host plant, the bacterium produces different virulence factors such as toxins, ice nucleation proteins, antimicrobial resistance, and secreted effectors which are the best studied virulence-associated factors $(1,12$, $33,44)$. $P$. syringae produces a powerful arsenal of toxins depending on the pathovar $(5,9,75)$. In 2003, Arrebola et al. (4) reported the preliminary characterization of an antimetabolite toxin produced primarily by $P$. syringae pv. syringae strains isolated from mango (thus called "mangotoxin"). Recent studies have since described mangotoxin production in some strains from pvs. avellanae (54) and pisi (15). The resistance of many $P$. syringae strains to antimicrobial compounds is well known (56). Copper compounds have been used for decades to control $P$. syringae infection of crops and to also control BAN in mango crops (16). Copper resistance has been frequently associated with native plasmids $(23,43)$, even in the $P$. syringae pv. syringae strains isolated from mango, where this resistance is mostly associated with $62-\mathrm{kb}$ native plasmids $(17,32)$.

The initial goal of this study was to evaluate the epidemiological structure of the $P$. syringae pv. syringae strains isolated from mango using different approaches. This aim was also extended to characterize the phylogenetic position of the mango isolates into pv. syringae and $P$. syringae spp. The results, based on genetic and phenotypic evidence, showed that $P$. syringae pv. syringae strains isolated from mango formed a differentiated cluster separate from most of the $P$. syringae pv. syringae strains isolated from other hosts. Moreover, together with the MLST data, a differentiated phylotype of pv. syringae strongly associated with mangotoxin production and adapted mainly to the mango host is proposed and discussed in this study.

\section{MATERIALS AND METHODS}

Bacterial strains and growth conditions. A group of 87 $P$. syringae pv. syringae strains isolated from mango from different areas, but mainly from Southern Spain, along with 28 strains isolated from different hosts $(n=19)$, different pathovars $(n=7)$, and different Pseudomonas spp. $(n=2)$ (Table 1; Supplemental Table 1) were initially selected and used for the genetic diversity study based on the rep-PCR technique. For the subsequent genetic and phenotypic analysis, a representative group of $51 P$. syringae pv. syringae strains isolated from mango, $6 P$. syringae $\mathrm{pv}$. syringae strains isolated from other hosts, and $2 P$. syringae strains from different pathovars were selected (Table 1). Three $P$. syringae pv. syringae strains isolated in Málaga (Spain) from other hosts ( $P$. syringae pv. syringae strains UMAF4007, UMAF6016, and UMAF6582) (Table 1) were used only for the evaluation of toxins production and for the phylogenetic analysis by MLST. Most of the $P$. syringae pv. syringae strains isolated from mango used in this work have been isolated in previous studies from different years (1990-2007) and different geographical locations in Spain $(4,20)$ and, to a lesser extent, Portugal, Italy, Israel, and Australia. The remaining strains used in this work were isolated from other hosts, and most of them were kindly provided by other laboratories. All strains were cultured in King's B (KB) (41) agar and Luria-Bertani (LB) broth media and incubated at $28^{\circ} \mathrm{C}$ for $24 \mathrm{~h}$.

Molecular fingerprinting techniques. Cultures for DNA extraction were grown overnight in LB broth at $28^{\circ} \mathrm{C}$ with shaking at $150 \mathrm{rpm}$, and DNA was extracted using the Jet Flex Extraction Kit (Genomed, Germany) according to the manufacturer's instruc- tions. PCR mixtures with final volumes of $25 \mu \mathrm{l}$ were prepared as follows: $10 \mathrm{ng}$ of template DNA, $2.5 \mu \mathrm{l}$ of $10 \times$ PCR buffer, and $2 \mu \mathrm{l}$ of dNTPS at $100 \mu \mathrm{M}$ each. A total of $2 \mu \mathrm{l}$ of each primer was used at a concentration of $10 \mu \mathrm{M}$ and $2.5 \mathrm{U}$ of Taq DNA polymerase (GE Healthcare Life Sciences). This mixture was the same for rep-PCR and RAPD-PCR analysis. The primer sets and the PCR amplification conditions for both fingerprinting techniques are summarized in Supplemental Table 2. All PCR amplifications were performed with a C1000 Thermal Cycler (Bio-Rad, UK). rep-PCR and RAPD-PCR patterns were visualized by agarose gel electrophoresis. Aliquots of $25 \mu \mathrm{l}$ (the volume for all amplifications) were loaded onto $1.2 \%$ Agarose D1 Low EEO (Pronadisa Laboratorios, Conda, Spain) gels and run in $1 \times$ Tris-acetate EDTA buffer (40 mM Tris-acetate and $1 \mathrm{mM}$ EDTA) at $80 \mathrm{~V} / \mathrm{cm}$ for $1.5 \mathrm{~h}$. Gels were stained with ethidium bromide at $0.4 \mu \mathrm{g} / \mathrm{ml}$ and visualized using a Gel Doc XR+ imaging system (Bio-Rad). Molecular weight analysis of patterns was performed with Quantity One software (version 4.2.1; Bio-Rad), using the Hyperladder I (1-kb DNA ladder) (Bioline, UK) as a molecular weight marker. Strains were tested in triplicate for both fingerprinting methods.

Polymorphic band patterns from rep-PCR ( $n=115$ strains) (Table 1) and RAPD-PCR ( $n=59$ strains) (Table 1) were individually identified by their specific electrophoretic migration rates. Once bands were identified, binary matrices $(0 / 1)$ were constructed to compare the patterns. The Jaccard's similarity coefficient was generated using InfoQuest FP software (Bio-Rad), and cluster analyses, along with their corresponding dendrograms, were generated by the unweighted pair-group method with average linkages (UPGMA) (67). Gel normalization and background subtraction were performed as previously described $(31,61)$.

Copper resistance and plasmid profile. Plasmid DNA from the selected strains (Table 1) was isolated according to a modified alkaline lysis method $(17,78)$ and separated by electrophoresis on $0.6 \%$ agarose gels. Plasmid size was estimated by comparison with the control strain $P$. syringae pv. tomato PT23 that harbors four plasmids (pPT23A, pPT23B, pPT23C, and pPT23D that are $100,83,65$, and $36 \mathrm{~kb}$ in size, respectively) (55). Copper resistance was determined by using mannitol-glutamate-yeast extract (MGY) agar medium (10) amended with $\mathrm{CuSO}_{4} \cdot 5 \mathrm{H}_{2} \mathrm{O}$. Bacteria previously grown for $24 \mathrm{~h}$ at $28^{\circ} \mathrm{C}$ on $\mathrm{LB}$ agar were used as inoculum. Strains growing on $\mathrm{MGY}+0.8 \mathrm{mM} \mathrm{CuSO}_{4}$ after $72 \mathrm{~h}$ at $28^{\circ} \mathrm{C}$ were considered resistant to copper.

Antibiotics resistance profile. Few antibiotics are appropriate for use in agriculture, and antibiotic-resistant strains are easily generated from their repetitive use. The selected strains (Table 1) were tested to determine their resistance or sensitivity to different antibiotics. These strains were freshly streaked from a single colony onto LB agar medium containing the following antibiotics: ampicillin $(100 \mu \mathrm{g} / \mathrm{ml})$, chloramphenicol $(25 \mu \mathrm{g} / \mathrm{ml})$, gentamicin $(10 \mu \mathrm{g} / \mathrm{ml})$, kanamycin $(50 \mu \mathrm{g} / \mathrm{ml})$, nitrofurantoin $(100 \mu \mathrm{g} / \mathrm{ml})$, spectinomycin $(50 \mu \mathrm{g} / \mathrm{ml})$, streptomycin $(100 \mu \mathrm{g} / \mathrm{ml})$, and tetracycline $(15 \mu \mathrm{g} / \mathrm{ml})$. Absence of bacterial growth after 24 and $48 \mathrm{~h}$ was considered sensitivity to the assayed antibiotic concentration.

Catabolic profile. The catabolic activities of the representative group of strains (Table 1) on 95 substrates were tested using a Biolog GN2 (Biolog) analysis according to the manufacturer's protocol, with minor modifications. Briefly, strains were grown on KB plates for $24 \mathrm{~h}$ and then colonies were scraped and suspended in $\mathrm{NaCl}$ solution at $4 \mathrm{~g} /$ liter until reaching an optical density (OD) of 0.15 to 0.2 at $590 \mathrm{~nm}$. Aliquots of $150 \mu \mathrm{l}$ were added to each well, color changes were measured at $590 \mathrm{~nm}$ using a microplate reader (Multiskan Ascent; Thermo Fisher Scientific) after 24 and $48 \mathrm{~h}$ of incubation at $28^{\circ} \mathrm{C}$, and the resulting data were corrected using the no-substrate control. The threshold value for a positive result was an OD of $\geq 0.350$ at $590 \mathrm{~nm}$. A binary matrix was constructed for cluster analysis by assigning a value for each substrate as follows: 0 for negative result (no catabolism) 
and 1 for positive result (catabolism). Two independent plates per each strain were used. The Jaccard's similarity coefficient was generated by the InfoQuest FP software (Bio-Rad), and cluster analysis along with its corresponding dendrogram was generated by UPGMA (67).

Antimetabolite toxin bioassay and dot blot hybridization analysis. The production of mangotoxin and phaseolotoxin was assayed by the indicator technique as previously described (26), with minor modifications (4). This method involves the growth inhibition of Escherichia coli on Pseudomonas minimal medium (PMS) (27). Briefly, a double layer of indicator microorganism was made using the E. coli strain CECT831. After solidification, the strains to be tested (Tables 1 and 2) were stabbed, and the plates were incubated at $22^{\circ} \mathrm{C}$ for $24 \mathrm{~h}$ and at $37^{\circ} \mathrm{C}$ for an addi-

TABLE 1. Representative group of Pseudomonas syringae strains used in this study

\begin{tabular}{|c|c|c|c|c|}
\hline P. syringae pathovar and strain & Geographical origin & Host plant & Year of isolation & Reference or source ${ }^{a}$ \\
\hline phaseolicola 1448A & Unknown (Ethiopia) & Bean & 1985 & 71 \\
\hline tomato DC3000 & Guernesey (United Kingdom) & Tomato & 1960 & 24 \\
\hline \multicolumn{5}{|l|}{ syringae (other hosts) } \\
\hline $1444-5$ & Madrid (Spain) & Laurel & 1995 & 4 \\
\hline 2676 & Lesotho (South Africa) & Bean & 1990 & 4 \\
\hline B728a & Wisconsin (United States) & Bean & & 35 \\
\hline EPS17A & Gerona (Spain) & Pear & 1987 & 4 \\
\hline EPSMV3 & Gerona (Spain) & Pear & 1990 & 4 \\
\hline FF5 & Oklahoma (United States) & Pear & 1988 & 68 \\
\hline UMAF4002 & Málaga (Spain) & Tomato & 1994 & 4 \\
\hline UMAF6016 & Málaga (Spain) & Chestnut & 1994 & 4 \\
\hline UMAF6582 & Málaga (Spain) & Peach & 1994 & 4 \\
\hline \multicolumn{5}{|l|}{ syringae (mango) } \\
\hline UMAF0001 & Málaga (Spain) & Mango & 1992 & 18 \\
\hline UMAF0005 & Málaga (Spain) & Mango & 1996 & 18 \\
\hline UMAF0048 & Málaga (Spain) & Mango & 1992 & 4 \\
\hline UMAF0049 & Málaga (Spain) & Mango & 1992 & 17 \\
\hline UMAF0081 & Málaga (Spain) & Mango & 1992 & 17 \\
\hline UMAF0092 & Málaga (Spain) & Mango & 1993 & UMA-LC \\
\hline UMAF0100 & Málaga (Spain) & Mango & 1990 & 4 \\
\hline UMAF0114 & Málaga (Spain) & Mango & 1991 & 4 \\
\hline UMAF0115 & Málaga (Spain) & Mango & 1991 & 4 \\
\hline UMAF0119 & Málaga (Spain) & Mango & 1991 & 18 \\
\hline UMAF0122 & Málaga (Spain) & Mango & 1991 & 4 \\
\hline UMAF0123 & Málaga (Spain) & Mango & 1991 & 18 \\
\hline UMAF0128 & Málaga (Spain) & Mango & 1992 & 18 \\
\hline UMAF0139 & Málaga (Spain) & Mango & 1995 & 4 \\
\hline UMAF0158 & Málaga (Spain) & Mango & 1993 & 17 \\
\hline UMAF0162 & Málaga (Spain) & Mango & 1997 & UMA-LC \\
\hline UMAF0166 & Málaga (Spain) & Mango & 1994 & 4 \\
\hline UMAF0167 & Málaga (Spain) & Mango & 1994 & 4 \\
\hline UMAF0170 & Málaga (Spain) & Mango & 1993 & 17 \\
\hline UMAF0171 & Málaga (Spain) & Mango & 1993 & 4 \\
\hline UMAF0176 & Málaga (Spain) & Mango & 1994 & 4 \\
\hline UMAF0186 & Málaga (Spain) & Mango & 2003 & UMA-LC \\
\hline UMAF0187 & Málaga (Spain) & Mango & 2003 & UMA-LC \\
\hline UMAF0209 & Málaga (Spain) & Mango & 2006 & 15 \\
\hline UMAF0214 & Málaga (Spain) & Mango & 2008 & 15 \\
\hline UMAF0511 & Málaga (Spain) & Mango & 1992 & 4 \\
\hline UMAF1012 & Málaga (Spain) & Mango & 1997 & 17 \\
\hline UMAF3028 & Málaga (Spain) & Mango & 1990 & 4 \\
\hline UMAF1003 & Huelva (Spain) & Mango & 1997 & 4 \\
\hline UMAF1029 & Huelva (Spain) & Mango & 1997 & 17 \\
\hline UMAF1051 & Huelva (Spain) & Mango & 1997 & 4 \\
\hline UMAF1060 & Huelva (Spain) & Mango & 1998 & 31 \\
\hline UMAF1094 & Huelva (Spain) & Mango & 2003 & 17 \\
\hline UMAF1105 & Huelva (Spain) & Mango & 2003 & UMA-LC \\
\hline UMAF1110 & Huelva (Spain) & Mango & 2003 & 17 \\
\hline UMAF1118 & Huelva (Spain) & Mango & 2003 & UMA-LC \\
\hline UMAF1128 & Huelva (Spain) & Mango & 2003 & 17 \\
\hline $1559-1$ & Huelva (Spain) & Mango & 1996 & 4 \\
\hline $1559-9$ & Huelva (Spain) & Mango & 1996 & 4 \\
\hline UMAF2007 & Almansil (Portugal) & Mango & 1997 & 4 \\
\hline UMAF2025 & Almansil (Portugal) & Mango & 1998 & 17 \\
\hline UMAF2026 & Almansil (Portugal) & Mango & 1998 & 17 \\
\hline UMAF2700 & Sicily (Italy) & Mango & 2002 & UMA-LC \\
\hline UMAF2702 & Sicily (Italy) & Mango & 2002 & 31 \\
\hline UMAF2801 & Canary Islands (Spain) & Mango & 2000 & 31 \\
\hline UMAF2802 & Canary Islands (Spain) & Mango & 2000 & 4 \\
\hline UMAF2808 & Canary Islands (Spain) & Mango & 2006 & UMA-LC \\
\hline DAR77787 & Dandaragan (Australia) & Mango & 2008 & 76 \\
\hline DAR77789 & Perth (Australia) & Mango & 2008 & 76 \\
\hline Ps 10 & Bet Dagan (Israel) & Mango & 1999 & 4 \\
\hline Ps35 & Bet Dagan (Israel) & Mango & 1999 & 4 \\
\hline
\end{tabular}

a UMA-LC: IHSM-UMA-CSIC, Microbiology and Plant Pathology laboratory collection (Málaga, Spain). 
tional 24-h period. To assess the biochemical step that is the putative target of the toxin, the same plate bioassay was performed but $100 \mu \mathrm{l}$ of a $6-\mathrm{mM}$ solution of the corresponding amino acid or intermediate ( $\mathrm{N}$-acetyl-Ornithine for mangotoxin and Ornithine for phaseolotoxin) was added to the double layer. Inhibition zones were observed for the mangotoxin- or phaseolotoxinproducing strains.

In addition, dot blot analysis was performed to confirm the presence of representative genes involved in toxin production (mangotoxin, phaseolotoxin, tabtoxin, and coronatine). The bacterial strains used as controls for toxin determination are listed in Table 2. The primers used to amplify the different toxins genes and their relevant characteristics are summarized in Supplemental Table 3. To generate the DNA probes for the different toxins, the PCR amplicons were cloned into the pCR2.1 vector (Invitrogen Corporation) and transformed into competent E. coli $\mathrm{DH} 5 \alpha$ cells. For dot blot assays, genomic DNA was isolated from single colonies grown overnight in LB broth in wells of a microtiter plate. In all, $200 \mu \mathrm{l}$ of $0.4 \mathrm{M} \mathrm{NaOH}$ and $10 \mathrm{mM}$ EDTA was added in each well. The plate was sealed with autoclave tape and incubated at $60^{\circ} \mathrm{C}$ for $15 \mathrm{~min}$; then, the plate was chilled on ice for $5 \mathrm{~min}$. Cell lysates from each strain were transferred into a nylon membrane using a Bio-Dot apparatus (Bio-Rad). Dot blot hybridizations were carried out using a DIG DNA labeling and detection kit (Roche Applied Science), following the manufacturer's instructions. The presence of signal indicated a positive result (presence of the representative genes involved in the toxins production).

Virulence assay on tomato leaflets. The pathogenicity tests using mango tissues are difficult and show low reproducibility. Therefore, in this study, the analysis of virulence on $P$. syringae pv. syringae strains isolated from mango was carried out using tomato leaflets to develop the disease symptoms $(3,6)$. To determine the virulence level of the studied strains (Table 1), inoculation experiments were performed using 'Hellfrucht Frühstamm' tomato (Lycopersicum esculentum L.) plants. The tomato plants were grown in a greenhouse under natural light. Tomato leaflets from 6- to 8-week-old plants were detached, disinfected in a $0.1 \%$ (wt/vol) $\mathrm{HgCl}_{2}$ solution, and placed in petri dishes with their petioles immersed in Murashige and Skoog (MS) agar medium (Sigma-Aldrich) (59). To determine differences in the virulence level, bacterial suspensions from exponential cultures were adjusted to $10^{6} \mathrm{CFU} / \mathrm{ml}$. Leaflets were inoculated by placing six $10-\mu l$ droplets of the bacterial suspension on the principal lateral veins, and inoculations were carried out by piercing through the droplets with an entomological pin, with a final inoculation dose of $\approx 10^{4} \mathrm{CFU}$ per inoculation point. The leaflets were maintained at $25^{\circ} \mathrm{C}$ under a $16-\mathrm{h}$ photoperiod. Four tomato leaflets were used to evaluate symptoms for each assayed strain. Leaflets treated with sterile water and maintained in MS medium were included in all the experiments as a control. This experiment was repeated twice. Therefore, 48 inoculation points were analyzed per strain, and all the data were analyzed together. The necrotic lesions produced on tomato leaflets by the inoculated strains were evaluated at 5 days postinoculation. A necrotic area $>1 \mathrm{~mm}$ surrounding the inoculation point was considered positive. The virulence degree was the percentage of necrotic points $(>1 \mathrm{~mm}$ in diameter) of each strain versus the total number of inoculated points. $P$. syringae pv. tomato DC3000 was used as positive control because it is a natural pathogen of tomato plants (Lycopersicum esculentum L.), and P. syringae pv. phaseolicola 1448A was used as negative control because it is not a pathogen of tomato, that should only produce a hypersensitive response. The virulence level was evaluated using the following scale: $<15 \%$, not pathogenic; $\geq 15$ to $<30 \%$, low virulence; $\geq 30$ to $<60 \%$, intermediate virulence; and $\geq 60 \%$, high virulence.

MLST analysis. For this experiment, a group of 55 P. syringae strains was selected, including $24 P$. syringae pv. syringae strains isolated from mango and coinciding with the maximum diversity showed in this work by genetic and phenotypic traits; 3 P. syringae pv. syringae strains isolated from pear; 12 P. syringae pv. syringae and $P$. syringae pv. phaseolicola 1448 A strains isolated from bean; $10 P$. syringae pv. syringae strains isolated from cherry; 1 P. syringae pv. syringae strain each isolated from laurel, tomato, peach, and chestnut; and P. syringae pv. tomato DC3000 isolated from tomato were analyzed by MLST. Partial sequences of the housekeeping genes $r p o D$ and $g y r B$ were obtained from a National Center for Biotechnology Information database or directly from purified PCR products amplified with primer sets rpoDFor2 (ACCGATCCCGTTCGTATGTA) and rpoDRev2 (TGGTGTACTTCTTGGCGATG) and gyrBFor2 (GTCATCAT GACCGTGCTCCA) and gyrBRev2 (CCCTTCCACCAGGTAC AGTT), respectively, as previously described (54). Partial sequences of $r p o D$ (807 nucleotides [nt]) and $\operatorname{gyrB}(890 \mathrm{nt})$ were concatenated for each strain and treated as a single sequence for multiple alignments using ClustalW2 (42). Phylogenetic trees were generated using MEGA 5.05 (70) with neighbor-joining, minimum evolution, and the option of complete deletion to eliminate positions containing gaps. Confidence levels of the branching points were determined using 10,000 bootstrap replicates. Nucleotide sequences were determined at Macrogen (Seoul, Korea) directly from purified PCR products. The accession numbers of the determined sequences used in this study are included in Supplemental Table 4.

\section{RESULTS}

rep-PCR revealed strong clustering depending on the host and area of isolation. DNA fingerprinting analysis was initially carried out using four different primer sets (ERIC, BOX, GTG-5, and CAG-5) on the complete group of selected strains $(n=115)$ (Table 1). The distribution tree generated (Fig. 1) was the result of analyzing all the fingerprinting data from the four different primers together. Individual analysis for each primer showed similar results (data not shown). This combined analysis revealed a strong clustering of $P$. syringae pv. syringae strains isolated from mango as well as a clear distribution by area of isolation (Fig. 1). The strains from two different Pseudomonas spp. and pathovars of $P$. syringae different from pv. syringae clustered separately. The group of strains marked in light gray was formed primarily by different subclusters of $P$. syringae pv. syringae strains isolated from hosts other than mango and two strains from different pathovars but belonging to the genomospecies 1 ( $P$. syringae pv. pisi P123R6 and $P$. syringae pv. avellanae ISPaVe2056).

TABLE 2. Bacterial strains used as control for toxin production

\begin{tabular}{|c|c|c|}
\hline Pseudomonas syringae pvs. & Relevant characteristics ${ }^{a}$ & Reference or source \\
\hline glycinea $49 \mathrm{a} / 90$ & Glycine $\max , 1990$, Germany; coronatine producer & 73 \\
\hline phaseolicola $1448 \mathrm{~A}$ & Phaseolus vulgaris, 1985, Ethiopia; phaseolotoxin producer & 71 \\
\hline syringae UMAF0158 & Mangifera indica, $1993, \mathrm{Nf}^{\mathrm{r}}$ wild type strain, Spain; mangotoxin producer & 17 \\
\hline syringae $\mathrm{CFBP} 3388$ & Vicia sativa, 1995, France; phaseolotoxin and mangotoxin producer & 72 \\
\hline tabaci BR2R & Phaseolus vulgaris, 1979, Rif $^{\mathrm{r}}$ isolate, Brazil; tabtoxin producer & 62 \\
\hline tomato DC3000 & Lycopersicum esculentum, 1960, Rif $^{\mathrm{r}}$ derivative of NCPPB1106, United Kingdom; coronatine producer & 24 \\
\hline
\end{tabular}

${ }^{a} \mathrm{Nf}^{\mathrm{r}}$ and $\mathrm{Rif}^{\mathrm{r}}$ indicate resistant to nitrofurantoin and rifampicin, respectively. 
Finally, a main cluster, marked in dark gray, consisted almost exclusively of $P$. syringae pv. syringae strains isolated from mango, and it was subsequently divided into different subclusters associated basically with the geographical origin of the mango isolates. Thus, we can distinguish three different subcluster groupings: the $P$. syringae pv. syringae strains isolated from mango in Málaga (Spain), those isolated from Huelva (a separate region of Spain), and those isolated from different regions worldwide (Australia, Israel, Italy, Portugal, and Canary Islands). Furthermore, only three $P$. syringae pv. syringae strains (UMAF1198, UMAF0005, and Ps-6) were located outside of the main clusters of $P$. syringae pv. syringae isolated from mango, and these strains differed greatly from the rest of $P$. syringae pv. syringae strains isolated from this host. Finally, the rep-PCR analysis was also conducted with the representative group of selected strains (Table 1), and a similar distribution was obtained (Supplemental Figure 1), maintaining the main clustering by host and an internal subclustering by geographical isolation.

TABLE 3. Plasmid profile and copper resistance of the representative group of strains

\begin{tabular}{|c|c|c|c|}
\hline Bacterial strains & Isolated from & Plasmid profile $(\mathrm{kb})$ & $\mathrm{CuSO}_{4} \cdot 5 \mathrm{H}_{2} \mathrm{O}(\mathrm{R} \text { or S } 0.8 \mathrm{mM})^{\mathrm{a}}$ \\
\hline \multicolumn{4}{|c|}{ Pseudomonas syringae pvs. } \\
\hline phaseolicola $1448 \mathrm{~A}$ & Unknown, Ethiopia & 131,51 & $\mathrm{~S}$ \\
\hline tomato DC3000 & Guernesey, United Kingdom & 73,67 & $\mathrm{~S}$ \\
\hline \multicolumn{4}{|c|}{ P. syringae pv. syringae (other hosts) } \\
\hline $1444-5$ & Madrid, Spain & 62 & $\mathrm{R}$ \\
\hline 2676 & Lesotho, South Africa & Plasmidless & $\mathrm{S}$ \\
\hline B728a & Wisconsin, United States & Plasmidless & $\mathrm{R}$ \\
\hline EPS17A & Gerona, Spain & Plasmidless & $\mathrm{R}$ \\
\hline EPSMV3 & Gerona, Spain & Plasmidless & $\mathrm{R}$ \\
\hline FF5 & Oklahoma, United States & Plasmidless & $\mathrm{S}$ \\
\hline \multicolumn{4}{|c|}{ P. syringae pv. syringae (mango) } \\
\hline UMAF0001 & Málaga, Spain & 88,62 & $\mathrm{R}$ \\
\hline UMAF0005 & Málaga, Spain & Plasmidless & $\mathbf{R}$ \\
\hline UMAF0048 & Málaga, Spain & 62 & $\mathrm{R}$ \\
\hline UMAF0049 & Málaga, Spain & 88,62 & $\mathrm{R}$ \\
\hline UMAF0081 & Málaga, Spain & 62 & $\mathrm{R}$ \\
\hline UMAF0092 & Málaga, Spain & 62 & $\mathrm{R}$ \\
\hline UMAF0100 & Málaga, Spain & Plasmidless & $\mathrm{S}$ \\
\hline UMAF0114 & Málaga, Spain & 120 & $\mathrm{R}$ \\
\hline UMAF0115 & Málaga, Spain & Plasmidless & $\mathbf{R}$ \\
\hline UMAF0119 & Málaga, Spain & 88,62 & $\mathrm{R}$ \\
\hline UMAF0122 & Málaga, Spain & 88,62 & $\mathrm{R}$ \\
\hline UMAF0123 & Málaga, Spain & 88,62 & $\mathrm{R}$ \\
\hline UMAF0128 & Málaga, Spain & 62 & $\mathrm{R}$ \\
\hline UMAF0139 & Málaga, Spain & 88,62 & $\mathrm{R}$ \\
\hline UMAF0158 & Málaga, Spain & 62 & $\mathrm{~S}$ \\
\hline UMAF0162 & Málaga, Spain & 62 & $\mathrm{R}$ \\
\hline UMAF0166 & Málaga, Spain & 120 & $\mathrm{R}$ \\
\hline UMAF0167 & Málaga, Spain & 120 & $\mathrm{R}$ \\
\hline UMAF0170 & Málaga, Spain & 62 & $\mathrm{R}$ \\
\hline UMAF0171 & Málaga, Spain & Plasmidless & $\mathbf{R}$ \\
\hline UMAF0176 & Málaga, Spain & 62 & $\mathrm{~S}$ \\
\hline UMAF0186 & Málaga, Spain & 62 & $\mathrm{R}$ \\
\hline UMAF0187 & Málaga, Spain & 62 & $\mathrm{R}$ \\
\hline UMAF0209 & Málaga, Spain & Plasmidless & $\mathrm{S}$ \\
\hline UMAF0214 & Málaga, Spain & 62 & $\mathrm{~S}$ \\
\hline UMAF0511 & Málaga, Spain & 62 & $\mathrm{R}$ \\
\hline UMAF1012 & Málaga, Spain & 62 & $\mathrm{R}$ \\
\hline UMAF3028 & Málaga, Spain & 45 & $\mathrm{R}$ \\
\hline UMAF1003 & Huelva, Spain & Plasmidless & $\mathrm{S}$ \\
\hline UMAF1029 & Huelva, Spain & 62 & $\mathrm{~S}$ \\
\hline UMAF1051 & Huelva, Spain & Plasmidless & $\mathbf{R}$ \\
\hline UMAF1060 & Huelva, Spain & 62 & $\mathrm{~S}$ \\
\hline UMAF1094 & Huelva, Spain & 62 & $\mathrm{~S}$ \\
\hline UMAF1105 & Huelva, Spain & 62 & $\mathrm{~S}$ \\
\hline UMAF1110 & Huelva, Spain & 62 & $\mathrm{R}$ \\
\hline UMAF1118 & Huelva, Spain & 62 & $\mathrm{R}$ \\
\hline UMAF1128 & Huelva, Spain & 62,45 & $\mathrm{R}$ \\
\hline $1559-1$ & Huelva, Spain & 62 & $\mathrm{~S}$ \\
\hline $1559-9$ & Huelva, Spain & 62 & $\mathrm{~S}$ \\
\hline UMAF2007 & Almansil, Portugal & Plasmidless & $\mathbf{R}$ \\
\hline UMAF2025 & Almansil, Portugal & Plasmidless & $\mathbf{R}$ \\
\hline UMAF2026 & Almansil, Portugal & 45 & $\mathrm{R}$ \\
\hline UMAF2700 & Sicily, Italy & Plasmidless & $\mathbf{R}$ \\
\hline UMAF2702 & Sicily, Italy & 62 & $\mathrm{~S}$ \\
\hline UMAF2801 & Canary Islands, Spain & 62 & $\mathrm{~S}$ \\
\hline UMAF2802 & Canary Islands, Spain & Plasmidless & $\mathrm{S}$ \\
\hline UMAF2808 & Canary Islands, Spain & Plasmidless & $\mathrm{S}$ \\
\hline DAR77787 & Dandaragan, Australia & Plasmidless & $\mathbf{R}$ \\
\hline DAR77789 & Perth, Australia & 62 & $\mathrm{R}$ \\
\hline Ps 10 & Bet Dagan, Israel & Plasmidless & $\mathbf{R}$ \\
\hline Ps35 & Bet Dagan, Israel & 62 & $\mathrm{R}$ \\
\hline
\end{tabular}

a Strains able to grow at $0.8 \mathrm{mM}$ are considered resistant to copper. $\mathrm{R}=$ resistant, $\mathrm{S}=$ sensitive, and bold = plasmidless copper-resistant strains. 
RAPD-PCR cluster of the $P$. syringae pv. syringae strains isolated from mango. Three primers (OPA-04, OPA-10, and OPA-13) were selected in a preliminary setup to assess the genetic diversity in the representative group of strains (Table 1).
The different fingerprinting patterns obtained with the different primers were analyzed individually, and then all combined (Fig. 2 ). The combined analysis of the three different fingerprinting patterns resulted in a more robust dendrogram with a similar ten-

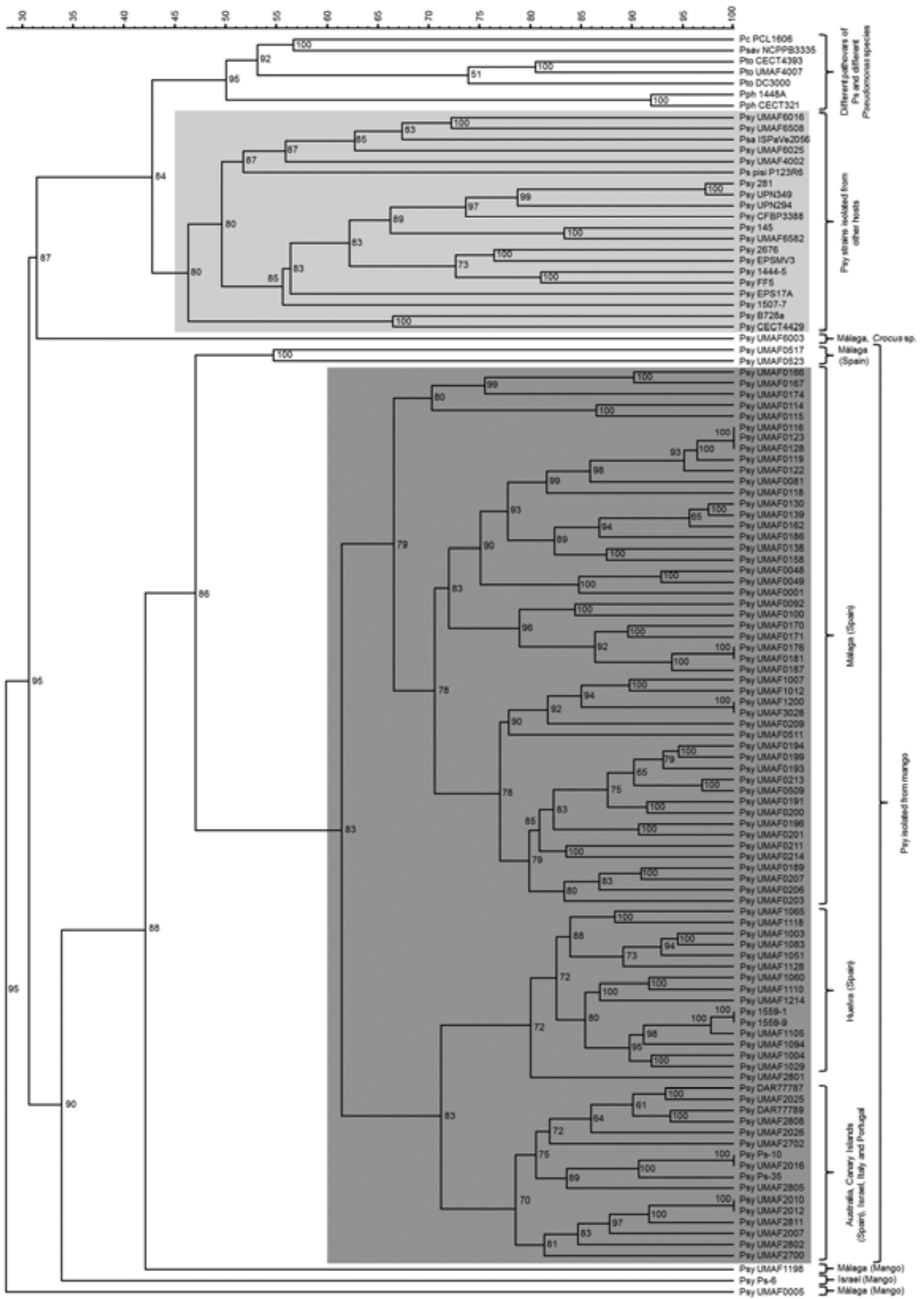

Fig. 1. Dendrogram cluster analysis using combined data obtained from the four different repetitive sequence-based polymerase chain reaction fingerprinting methods (ERIC, BOX, GTG-5, and CAG-5), showing genetic relationships of Pseudomonas syringae pv. syringae isolated from mango trees, with isolates from other hosts and with other pathovars of $P$. syringae. Jaccard's similarity coefficient was used to generate a consensus tree with InfoQuest FP software (Bio-Rad), using the unweighted pair-group method with average linkages. Light gray box: P. syringae pv. syringae strains isolated from other hosts than mango, and dark gray box: $P$. syringae pv. syringae strains isolated from mango forming different subgroups based on the area of isolation. Table 1 provides detailed information of the strains $(n=115)$ 
dency to each separate one (data not shown). The resulting RAPD-PCR dendrogram (Fig. 2) showed a number of clusters. The main cluster, marked in gray, consisted primarily of the $P$. syringae pv. syringae strains isolated from mango $(n=48$, representing the $94.1 \%$ of the strains isolated from mango), excluding the three $P$. syringae pv. syringae strains isolated from mango in Portugal. This cluster also included a $P$. syringae pv. syringae strain isolated from pear $(P$. syringae pv. syringae EPS17A). The rest of the $P$. syringae pv. syringae strains isolated from other hosts $(n=5)$ and different pathovars of $P$. syringae $(P$. syringae pv. tomato DC3000 and $P$. syringae pv. phaseolicola 1448A), along with the three $P$. syringae pv. syringae strains isolated from mango in Portugal, were grouped separately from the main cluster of the mango isolates.

The plasmid and copper resistance distribution. The distribution pattern of the native plasmids in the representative group of strains and their possible relationship with copper resistance (Table 3) was studied. Different plasmid profiles, such as the

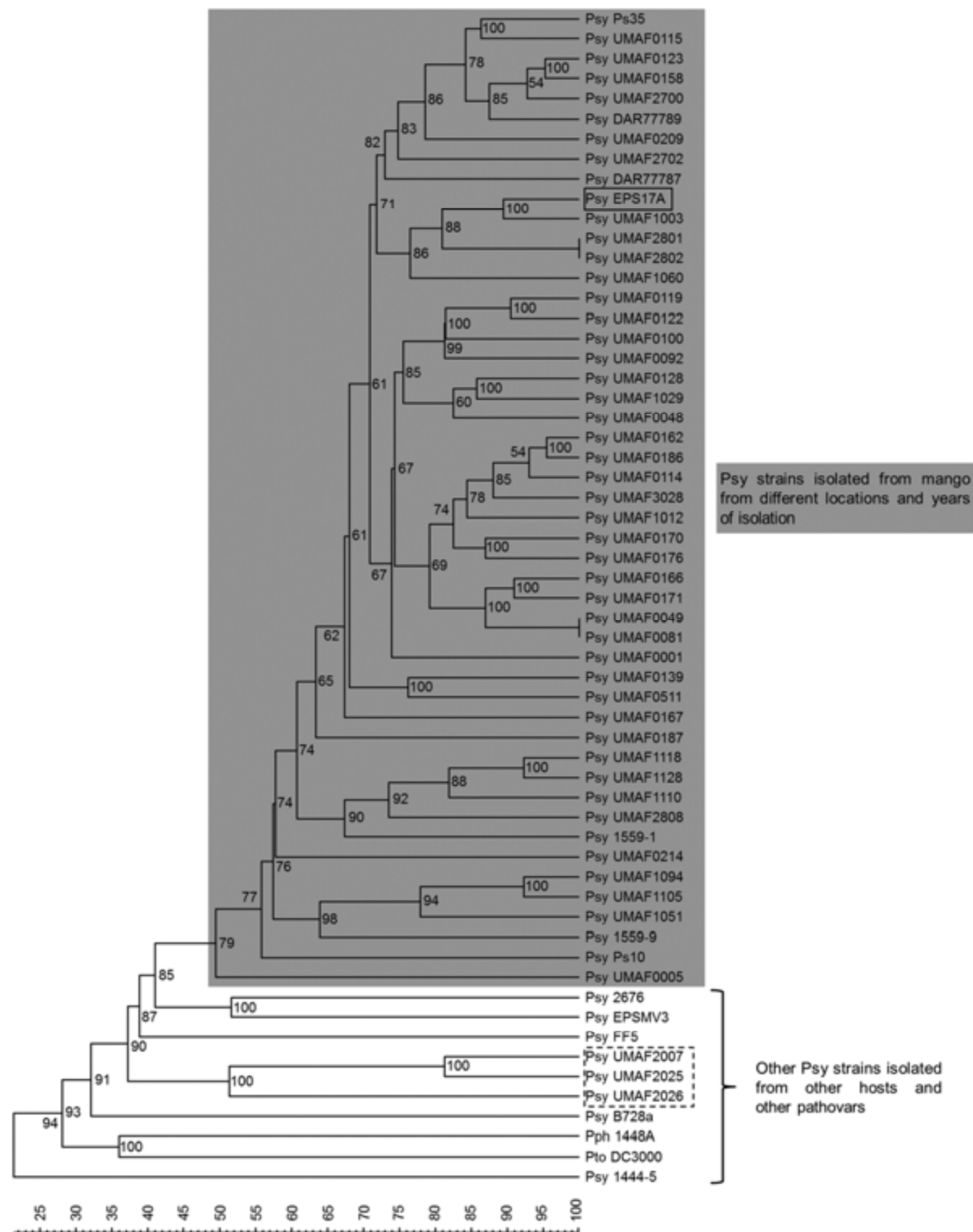

Fig. 2. Dendrogram produced by cluster analysis of the representative group of the strains based on the data obtained from the three different randomly amplified polymorphic DNA polymerase chain reaction fingerprints analyzed (OPA-04, OPA-10, and OPA-13). Banding patterns were compared between strains using the Jaccard's similarity coefficient and unweighted pair-group method with average linkages to generate a consensus tree with InfoQuest FP software (Bio-Rad). Gray box: Pseudomonas syringae pv. syringae strains isolated from mango. Black box: P. syringae pv. syringae EPS17A strain isolated from pear. Dashed box: P. syringae pv. syringae strains isolated from mango in Portugal (UMAF2007, UMAF2025, and UMAF2026). Table 1 provides detailed information of the strains. 
different $62-\mathrm{kb}$ plasmids, some of which are related to copper resistance, were observed and consistent with previous reports (17). Only 14 of the 51 strains isolated from mango were plasmidless; 37 harbored plasmids and 32 of those contained a $62-\mathrm{kb}$ plasmid, either alone or together with other plasmids. The $62-\mathrm{kb}$ plasmids were found in 21 copper-resistant and 11 copper-sensitive strains. The presence of a $120-\mathrm{kb}$ plasmid was also observed in three $P$. syringae pv. syringae strains (UMAF0114, UMAF0166, and UMAF0167), which was previously associated with copper resistance $(17,18)$. In summary, of the $51 P$. syringae pv. syringae strains isolated from mango, 32 of them $(\approx 62.7 \%)$ contained a 62 -kb plasmid and 21 of these $(\approx 66 \%)$ were copper-resistant strains.

Heterogeneous distribution of antibiotic resistance. The antibiotic resistance of the selected strains (Table 1) is summarized in Table 4. All the strains tested showed resistance to nitrofurantoin. Similarly, a high number of $P$. syringae pv. syringae strains isolated from mango were resistant to ampicillin (62.7\%), distributed randomly in different clusters obtained by the genetic diversity analysis. In contrast, none of these strains were able to grow in kanamycin. Interestingly, two multi-resistant antibiotic strains were detected, UMAF0005 and UMAF3028. Both were able to grow in ampicillin, chloramphenicol, nitrofurantoin, spectinomycin, streptomycin, and tetracycline. In addition, strain UMAF0005 was also resistant to gentamicin, showed genetic traits different from other $P$. syringae pv. syringae strains isolated from mango, and was more divergent from the other mango isolates when analyzed by RAPD and even more so by rep-PCR analysis.

Catabolic diversity supports the genetic distribution. The catabolic activities of the $P$. syringae pv. syringae strains on 95 substrates were determined using a Biolog GN2 (Biolog), and these results were used to construct a dendrogram based on the ability of the bacterial strains to grow using these substrates as unique carbon sources. This phenotypic distribution tree (Fig. 3) again showed an interesting association of the majority of the $P$. syringae pv. syringae strains isolated from mango in contrast with the $P$. syringae pv. syringae strains from other hosts and with other pathovars of $P$. syringae. This phenotypic analysis generated a number of separate clusters, of which the main cluster grouped together the majority of the $P$. syringae pv. syringae strains isolated from mango (45 P. syringae pv. syringae strains, $88 \%$ of the mango isolates). The rest of the $P$. syringae pv. syringae strains isolated from other hosts and the five $P$. syringae pv. syringae strains isolated from mango from different countries (three strains from Portugal and one strain each from Spain and Italy) were grouped together separately from the main cluster. $P$. syringae pv. tomato DC3000 and P. syringae pv. phaseolicola 1448A, strains used as external controls, and $P$. syringae pv. syringae UMAF0005 were located completely outside from these clusters.

Mangotoxin is a specific phenotypic trait of $P$. syringae pv. syringae strains isolated from mango. Mangotoxin is an antimetabolite toxin produced by $P$. syringae pv. syringae strains isolated from mango (4). Mangotoxin production was tested by an indicator technique based on the growth inhibition bioassay of $E$. coli in PMS and by dot blot detection of an amplicon of the mangotoxin biosynthetic operon $(\mathrm{mbo})$ operon involved in the biosynthesis of mangotoxin. Most of the $P$. syringae pv. syringae strains isolated from mango were positive for mangotoxin production with both indicator and dot blot techniques (Table 5). $P$. syringae pv. syringae strain UMAF3028 was the unique exception because it did not produce $m b o$ amplicon and was negative for mangotoxin production. The mbo amplicon was also detected in five strains isolated from other hosts: P. syringae pv. syringae 1444-5, FF5, EPS17A, CFBP3388, and UMAF4002. Strains EPS17A isolated from pear, CFBP3388 isolated from Vicia sativa, and UMAF4002 isolated from tomato were able to produce mangotoxin $(15,54)$. Production of the other toxins analyzed in this study (phaseolotoxin, tabtoxin, and coronatine) was only observed in the expected reference strains of the corresponding pathovar. However, none of the $P$. syringae pv. syringae strains isolated from mango produce any of these toxins, which confirms that $P$. syringae pv. syringae strains isolated from mango specifically produce mangotoxin (Table 5).

Virulence level on tomato leaflets. The virulence level on tomato leaflets of the representative strains is represented in Figure 4. The number of necrotic spots $>1 \mathrm{~mm}$ in diameter was recorded at 5 days postinoculation. The results from the different inoculated tomato leaflets were represented in percentages, following the scale described in Materials and Methods (Fig. 4). Seventeen $P$. syringae pv. syringae strains isolated from mango $(33.3 \%)$ showed a low degree of virulence $(\geq 15$ and $<30 \%$ of necrotic spots). This virulence group included two strains not belonging to the $P$. syringae pv. syringae strains isolated from mango (B728a and 1444-5). As expected, the negative control strain $P$. syringae pv. phaseolicola 1448A was considered not pathogenic together with the $P$. syringae pv. syringae strain UMAF0005 isolated from mango, a strain that was also separated from the $P$. syringae pv. syringae mango group by other traits. The majority of $P$. syringae pv. syringae strains isolated from mango (60.8\%) showed an intermediate degree of virulence $(\geq 30$ to $<60 \%)$. In addition, this virulence group included three $P$. syringae pv. syringae strains isolated from other hosts (FF5, 2676, and EPS17A). Finally, the highly virulent group $(>60 \%)$ included only three $P$. syringae pv. syringae strains isolated from mango (DAR77789, UMAF0171, and UMAF0214; 5.9\%) from different geographical areas, a $P$. syringae pv. syringae strain isolated from pear (EPSMV3), and the positive control strain $P$. syringae pv. tomato DC3000 (a tomato pathogen). The virulence level was distributed heterogeneously among the $P$. syringae pv. syringae strains isolated from mango and was not associated with any of the genetic or biochemical grouping in this work.

Phylogenetic analysis reveals a differentiated phylotype of $P$. syringae pv. syringae strains isolated from mango. Four main MLST phylogroups were clearly generated (Fig. 5), showing a similar tendency, consistent with results previously observed by rep-PCR, RAPD, and Biolog GN2 analysis. The different isolates were clearly grouped based on the host of isolation, being highly relevant to mangotoxin production, and do not show any relation

TABLE 4. Distribution of the antibiotic resistance on the representative group of strains

\begin{tabular}{|c|c|c|c|c|c|c|c|c|}
\hline \multirow[b]{2}{*}{ P. syringae pvs. ${ }^{\mathrm{a}}$} & \multicolumn{8}{|c|}{ Antibiotics resistance $^{b}$} \\
\hline & Amp & $\mathrm{Cm}$ & $\mathrm{Gm}$ & $\mathrm{Km}$ & $\mathrm{Nf}$ & $\mathrm{Sp}$ & $\mathrm{Sm}$ & Tet \\
\hline syringae $($ mango, $n=51)$ & 32 & 4 & 1 & NR & 51 & 2 & 2 & 2 \\
\hline syringae (other hosts, $n=6$ ) & 3 & 2 & NR & NR & 6 & NR & 1 & NR \\
\hline phaseolicola $1448 \mathrm{~A}$ (bean, $n=1$ ) & NR & NR & NR & NR & 1 & NR & NR & NR \\
\hline tomato DC3000 (tomato, $n=1$ ) & NR & NR & NR & NR & 1 & NR & NR & NR \\
\hline
\end{tabular}

a Total number $(n)$ of strains tested shown in parentheses.

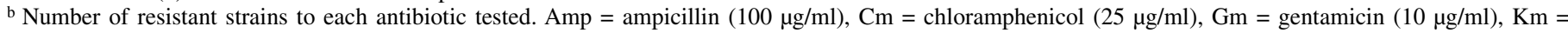
kanamycin $(50 \mu \mathrm{g} / \mathrm{ml}), \mathrm{Nf}=$ nitrofurantoin $(100 \mu \mathrm{g} / \mathrm{ml}), \mathrm{Sp}=$ spectinomycin $(50 \mu \mathrm{g} / \mathrm{ml}), \mathrm{Sm}=\operatorname{streptomycin}(100 \mu \mathrm{g} / \mathrm{ml})$, and Tet $=$ tetracycline $(15 \mu \mathrm{g} / \mathrm{ml}) . \mathrm{NR}=$ no resistance (0 strains resistant). 
with the area of isolation. The different MLST phylogroups were named as follows: Psy4 for $P$. syringae pv. syringae strains isolated from cherry; Psy3 for $P$. syringae pv. syringae strains isolated from bean and also including two $P$. syringae pv. syringae strains isolated from chestnut and peach in Málaga; Psy2 for $P$. syringae pv. syringae strains isolated from other hosts than mango (bean, pear, cherry, and laurel) that were mangotoxin producers or harbored the mbo genes related to its production detected by dot blot; and the Psy1 group, which included all the $P$. syringae pv. syringae mango isolates, mainly mangotoxin pro- ducers, with the exception of three $P$. syringae pv. syringae strains. Within the Psy1 group, strain UMAF3028 does not produce mangotoxin, although it was isolated from mango, and EPS17A isolated from pear and UMAF4002 isolated from tomato do produce mangotoxin.

\section{DISCUSSION}

P. syringae pv. syringae is distinguished from many other plant pathogens by its ability to infect a large variety of woody and

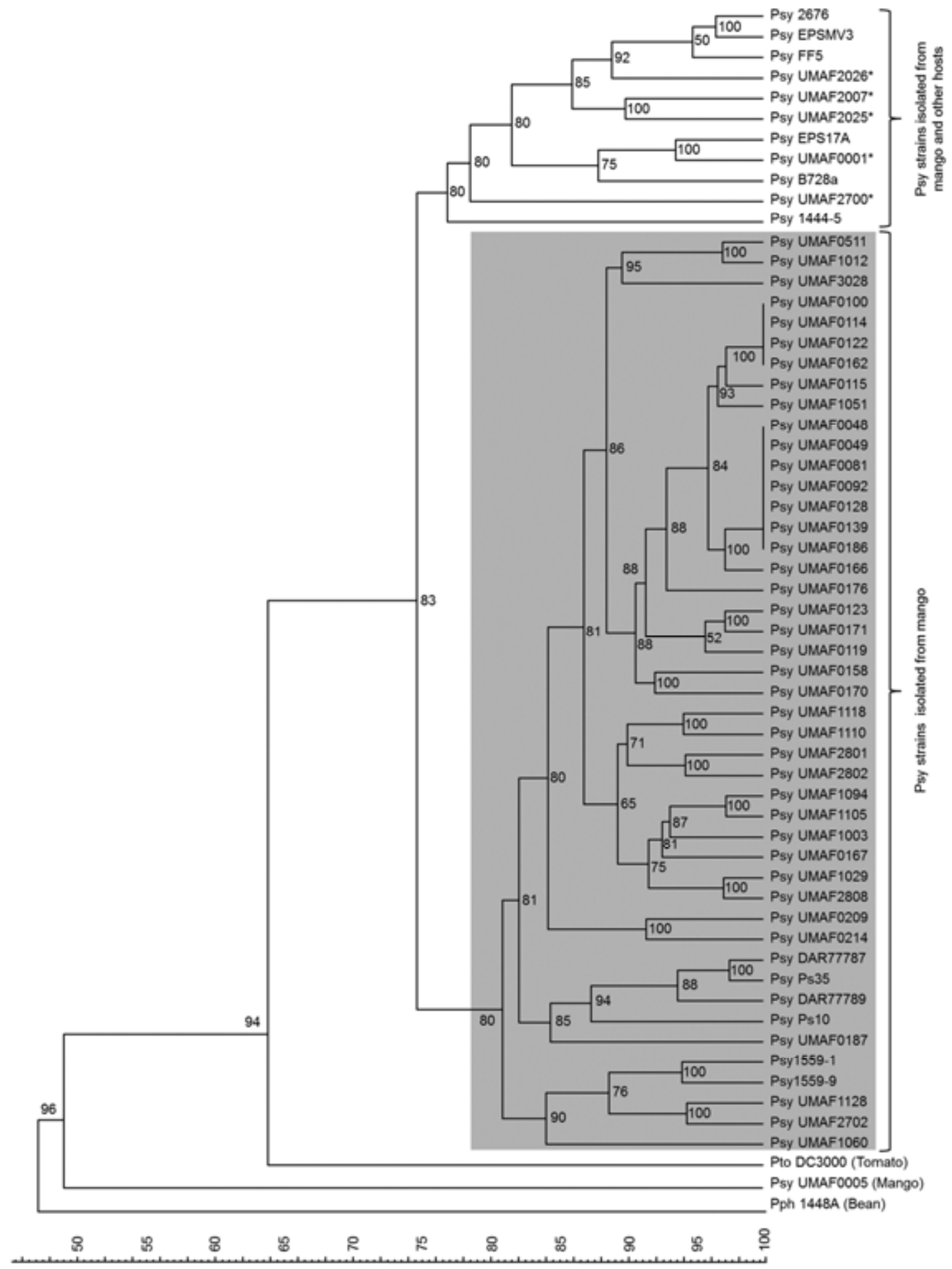

Fig. 3. Cluster analysis of the representative group of the strains $(n=59)$ based on their catabolic activities on 95 different substrates (Biolog GN2). Jaccard's similarity coefficient was used to generate a dendrogram using the InfoQuest FP software (Bio-Rad), and unweighted pair-group method with average linkages; * indicates five Pseudomonas syringae pv. syringae strains isolated from mango (UMAF0001, UMAF2700, UMAF2007, UMAF2025, and UMAF2026). Gray box: P. syringae pv. syringae strains isolated from mango. 
TABLE 5. Toxins production analyzed by Escherichia coli inhibition growth bioassay and dot-blot hybridization analysis ${ }^{\mathrm{a}}$

\begin{tabular}{|c|c|c|c|c|c|c|}
\hline \multirow[b]{2}{*}{ Bacterial strains } & \multicolumn{2}{|c|}{ Mangotoxin } & \multicolumn{2}{|c|}{ Phaseolotoxin } & \multirow{2}{*}{$\frac{\text { Tabtoxin }}{\text { Dot blot }}$} & \multirow{2}{*}{$\begin{array}{c}\text { Coronatine } \\
\text { Dot blot }\end{array}$} \\
\hline & Bioassay & Dot blot & Bioassay & Dot blot & & \\
\hline \multicolumn{7}{|c|}{ Pseudomonas syringae pvs. } \\
\hline $\begin{array}{l}\text { glycinea 49a/90 } \\
\text { phaseolicola } 1448 \mathrm{~A}\end{array}$ & $\begin{array}{l}- \\
-\end{array}$ & $\begin{array}{l}- \\
-\end{array}$ & $\overline{+}$ & $\bar{t}$ & $\begin{array}{l}- \\
-\end{array}$ & + \\
\hline tabaci BR2R & - & - & - & - & + & - \\
\hline tomato DC3000 & - & - & - & - & - & + \\
\hline tomato $\mathrm{PT} 23$ & - & - & - & - & - & + \\
\hline \multicolumn{7}{|l|}{ syringae (other hosts) } \\
\hline $1444-5$ & - & + & - & - & - & - \\
\hline 2676 & - & - & - & - & - & - \\
\hline B728a & - & - & - & - & - & - \\
\hline CFBP3388 & + & + & + & + & - & - \\
\hline EPS17A & + & + & - & - & - & - \\
\hline EPSMV3 & - & - & - & - & - & - \\
\hline FF5 & - & + & - & - & - & - \\
\hline UMAF4002 & + & + & - & - & - & - \\
\hline UMAF6016 & - & - & - & - & - & - \\
\hline UMAF6582 & - & - & - & - & - & - \\
\hline \multicolumn{7}{|l|}{ syringae (mango) } \\
\hline UMAF0001 & + & + & - & - & - & - \\
\hline UMAF0005 & + & + & - & - & - & - \\
\hline UMAF0048 & + & + & - & - & - & - \\
\hline UMAF0049 & + & + & - & - & - & - \\
\hline UMAF0081 & + & + & - & - & - & - \\
\hline UMAF0092 & + & + & - & - & - & - \\
\hline UMAF0100 & + & + & - & - & - & - \\
\hline UMAF0114 & + & + & - & - & - & - \\
\hline UMAF0115 & + & + & - & - & - & - \\
\hline UMAF0119 & + & + & - & - & - & - \\
\hline UMAF0122 & + & + & - & - & - & - \\
\hline UMAF0123 & + & + & - & - & - & - \\
\hline UMAF0128 & + & + & - & - & - & - \\
\hline UMAF0139 & + & + & - & - & - & - \\
\hline UMAF0158 & + & + & - & - & - & - \\
\hline UMAF0162 & + & + & - & - & - & - \\
\hline UMAF0166 & + & + & - & - & - & - \\
\hline UMAF0167 & + & + & - & - & - & - \\
\hline UMAF0170 & + & + & - & - & - & - \\
\hline UMAF0171 & + & + & - & - & - & - \\
\hline UMAF0176 & + & + & - & - & - & - \\
\hline UMAF0186 & + & + & - & - & - & - \\
\hline UMAF0187 & + & + & - & - & - & - \\
\hline UMAF0209 & + & + & - & - & - & - \\
\hline UMAF0214 & + & + & - & - & - & - \\
\hline UMAF0511 & + & + & - & - & - & - \\
\hline UMAF1012 & + & + & - & - & - & - \\
\hline UMAF3028 & - & - & - & - & - & - \\
\hline UMAF1003 & + & + & - & - & - & - \\
\hline UMAF1029 & + & + & - & - & - & - \\
\hline UMAF1051 & + & + & - & - & - & - \\
\hline UMAF1060 & + & + & - & - & - & - \\
\hline UMAF1094 & + & + & - & - & - & - \\
\hline UMAF1105 & + & + & - & - & - & - \\
\hline UMAF1110 & + & + & - & - & - & - \\
\hline UMAF1118 & + & + & - & - & - & - \\
\hline UMAF1128 & + & + & - & - & - & - \\
\hline $1559-1$ & + & + & - & - & - & - \\
\hline $1559-9$ & + & + & - & - & - & - \\
\hline UMAF2007 & + & + & - & - & - & - \\
\hline UMAF2025 & + & + & - & - & - & - \\
\hline UMAF2026 & + & + & - & - & - & - \\
\hline UMAF2700 & + & + & - & - & - & - \\
\hline UMAF2702 & + & + & - & - & - & - \\
\hline UMAF2801 & + & + & - & - & - & - \\
\hline UMAF2802 & + & + & - & - & - & - \\
\hline UMAF2808 & + & + & - & - & - & - \\
\hline DAR77787 & + & + & - & - & - & - \\
\hline DAR77789 & + & + & - & - & - & - \\
\hline Ps10 & + & + & - & - & - & - \\
\hline Ps35 & + & + & - & - & - & - \\
\hline
\end{tabular}

a Bold with gray shading indicates strains used as control of toxin production. Bold without shading indicates interesting strains and their relevant characteristics. P. syringae pv. syringae FF5 and 1444-5 are non-mangotoxin-producing strains but showed hybridization signal by dot blot. Strain CFBP3388 produces mangotoxin and phaseolotoxin. Strains EPS17A and UMAF 4002, isolated from pear and tomato, respectively, are mangotoxin producers and showed hybridization signal by dot blot. UMAF3028 is the only strain isolated from mango that does not produce mangotoxin and does not present hybridization signal. 
herbaceous plant species (40). This fact suggests a high degree of genetic variability in this pathovar that can provide understanding of the development of this plant pathogen in different hosts. In the current study, we evaluated the genetic, phenotypic, and phylogenetic diversity in a large collection of $P$. syringae pv. syringae strains isolated from mango (and in comparison with isolates from other hosts) that encompasses a wide range of geographical origins but is primarily from southern Spain.

rep-PCR is a commonly used technique because of its sensitivity and reproducibility, making it a highly discriminatory technique for assessing bacterial diversity at the strain and pathovar level with an epidemiological aim $(25,51,52,58,66,69)$. A previous study demonstrating the usefulness of this molecular fingerprinting technology was performed (31), showing the ability of some primers tested to produce repetitive fingerprinting patterns in $P$. syringae pv. syringae strains isolated from mango. When the 115 strains used in this study were genotyped by repPCR, a main cluster was observed composed almost exclusively of $P$. syringae pv. syringae strains isolated from mango, forming a distinct group associated with host of isolation and clearly separate from other $P$. syringae pv. syringae strains isolated from other hosts and other pathovars of $P$. syringae (Fig. 1). In contrast, a previous study using different $P$. syringae pv. syringae strains isolated from various woody and herbaceous plants did not show a clear relationship between the host plant and genomic fingerprinting (66). The rep-PCR technique also provides subcluster differentiation of the $P$. syringae pv. syringae mango isolates based on geographical origins (Fig. 1) but these data are not consistent with the recent results observed for $P$. syringae pv. syringae strains isolated from pea (52). Notably, clustering of the $P$. syringae pv. syringae mango isolates worldwide is stronger among them than with others isolates from different hosts that are closer geographically (for instance, southern Spain). Although few exceptions were observed, the reliability and robustness of the rep-PCR technique to cluster nearly all $P$. syringae pv. syringae strains from mango and to determine subgroups based on the area of isolation was confirmed.
Similarly, the RAPD-PCR fingerprinting method was able to differentiate the majority of the $P$. syringae pv. syringae strains isolated from mango from the $P$. syringae pv. syringae strains isolated from other hosts and other pathovars (Fig. 2). This technique was successfully used to characterize pathogenic races of $P$. syringae pv. pisi (2) and to distinguish pv. tomato from pv. maculicola (22), both of which belong to the genomospecies 3 . In this study, RAPD-PCR grouped pv. syringae strains based on the host of isolation. Despite the fact that these techniques (rep-PCR and RAPD-PCR) showed different resolution levels, both clustered together the $P$. syringae pv. syringae strains based on the host of isolation. These results suggest a possible genetic specialization of $P$. syringae pv. syringae strains, particularly in the mango host, as has been previously observed for the same pathovar in stone fruit (45) and in different bean pathovars (7).

MLST analysis has been previously performed to compare the phylogeny of $P$. syringae pathovars $(8,28,37,63)$. To determine whether the genetic clustering is consistent with the phylogeny of $P$. syringae, a MLST analysis using different housekeeping genes was performed that included $P$. syringae pv. syringae strains isolated from mango and other hosts (Fig. 5). This analysis generated four different phylogroups that were mainly clustered by the host of isolation. A similar result was previously observed for $P$. syringae pv. actinidiae isolated from kiwifruit, which allocated all the $P$. syringae pv. actinidiae strains in the same phylogroup with respect to other pathovars isolated from other hosts (21). In our study, the cluster named Psyl comprised all of the $P$. syringae pv. syringae strains isolated from mango worldwide, the majority of which are mangotoxin producers. Another interesting cluster is formed primarily by $P$. syringae pv. syringae strains isolated from different herbaceous and woody hosts (Psy2), and these strains are also mangotoxin producers, as was previously reported for pv. syringae and others pathovars belonging to the genomospecies $1(15,54)$. Therefore, mangotoxin production is a highly specific phenotypic trait for the $P$. syringae pv. syringae strains isolated from mango. Thus, mangotoxin production may be one of the most important traits, following a similar evolution-

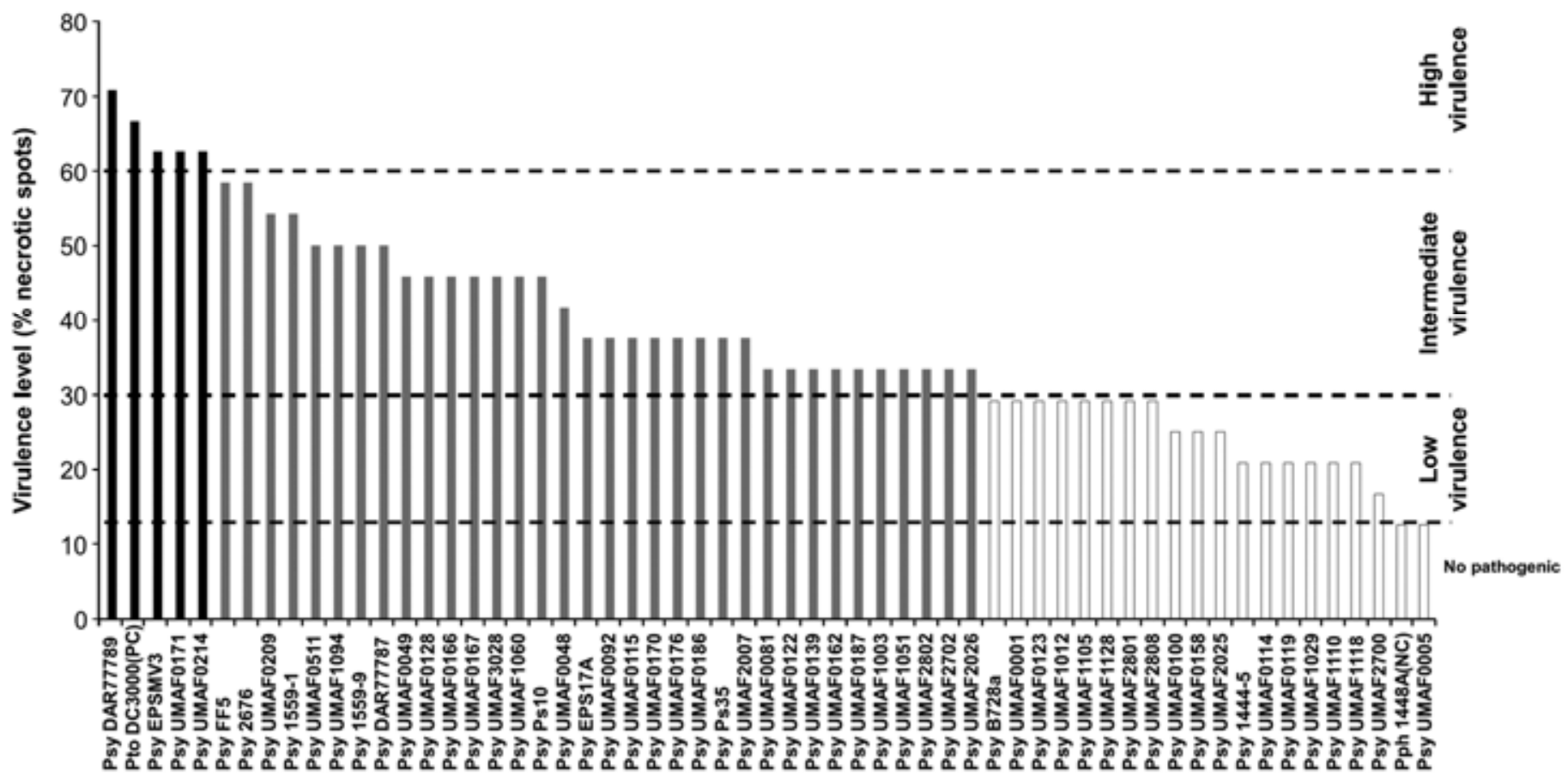

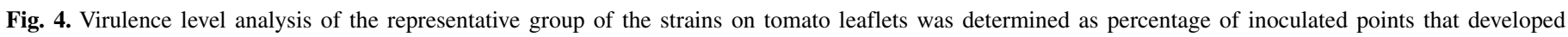

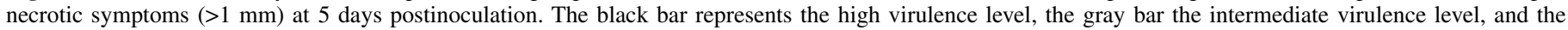

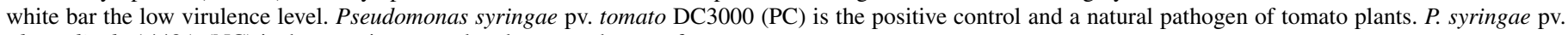
phaseolicola 1448A (NC) is the negative control and not a pathogen of tomato. 
ary history together with the adaptation to the determined host, such as mango. The presence of two other distinct groups of $P$. syringae pv. syringae strains isolated from bean and cherry (Fig. 5) that were non-mangotoxin producers suggests that $P$. syringae pv. syringae strains isolated from mango, which are mangotoxin producers, may constitute a differentiated phylotype within the heterogeneous pv. syringae.

Conversely, the phenotypic approaches to study the diversity of $P$. syringae pv. syringae strains isolated from mango also support their host specialization and separated lineage. The catabolic

MGTXPR: Mangotoxin production MGTXDB: Mangotoxin dot blot detection
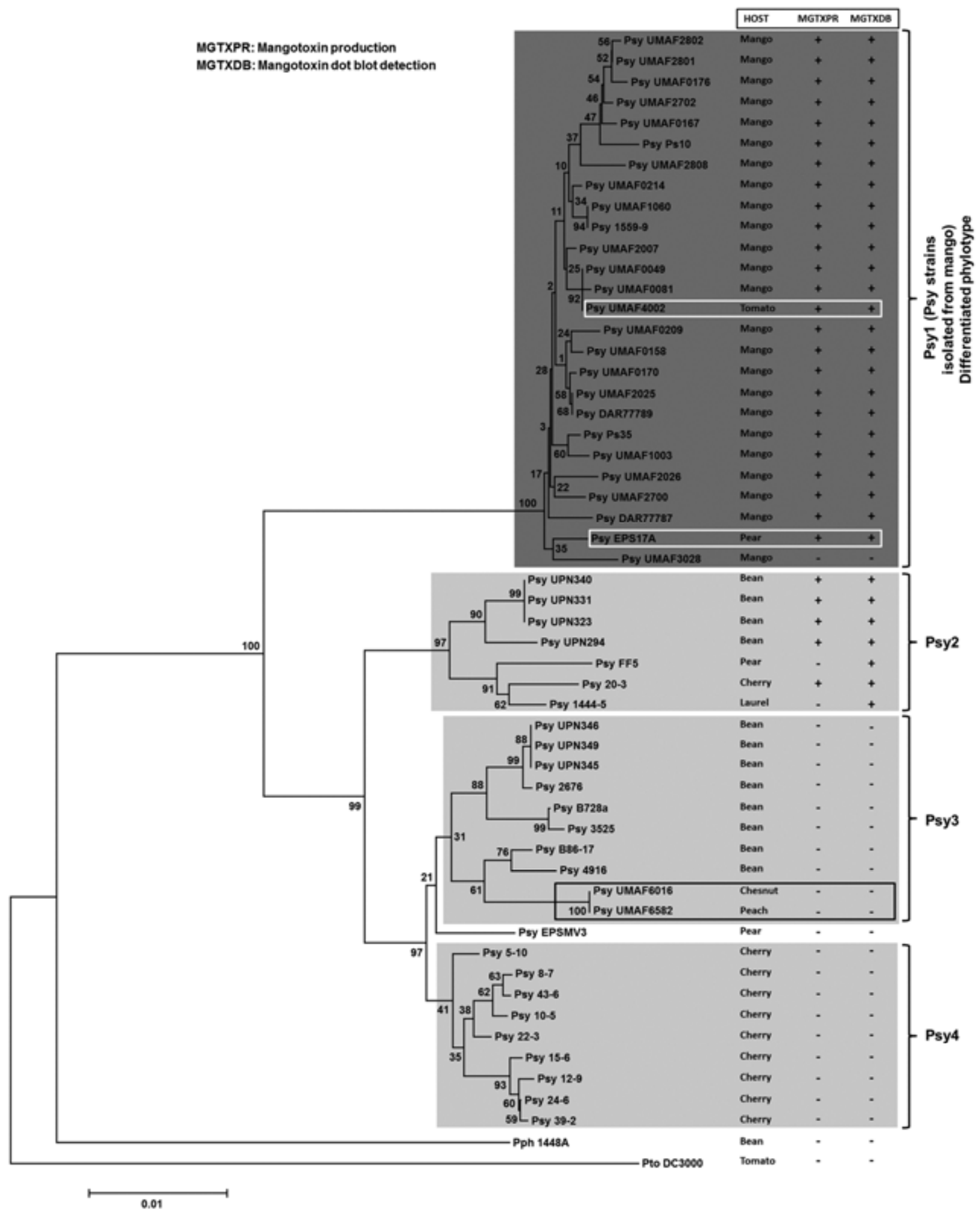

Fig. 5. Multilocus sequence typing analysis produced a phylogeny of Pseudomonas syringae strains. The neighbor-joining tree was constructed with combined partial sequences of $r p o D$ and gyrB genes using MEGA 5.0.5. The host of isolation, the mangotoxin production, and the presence of genes related to its production are represented in the right column beside each strain number. Bootstrap values (10,000 repetitions) are shown on branches and evolutionary distances are in units of nucleotide substitutions per site. Dark gray box: P. syringae pv. syringae strains isolated from mango and mangotoxin producer. White box: P. syringae pv. syringae strains isolated from other hosts and mangotoxin producer (UMAF4002 and EPS17A). Black box: P. syringae pv. syringae strains isolated in Málaga (Spain) from other hosts (UMAF6016 and UMAF6582) and not mangotoxin producer. Supplemental Table 4 provides detailed information of the strains and accession numbers of the DNA sequences used. 
diversity determined by Biolog GN2 analysis has been used to characterize different pathovars of $P$. syringae, clustering all of them together while internally subclustering each different pathovar (38). This system has also been used to separate pv. phaseolicola from other pathovars (34). In our study, Biolog GN2 analysis (Fig. 3) was able to discern P. syringae, even at an intrapathovar level, clustering the majority of $P$. syringae $\mathrm{pv}$. syringae strains isolated from mango together and separating them from other $P$. syringae pv. syringae strains isolated from other hosts and pathovars. Furthermore, the presence of 62-kb plasmids (Table 3) in $P$. syringae pv. syringae strains isolated from mango and their possible relationship with copper resistance could be revealing the important role that these plasmids have in the ecological fitness of this bacterium $(17,18,32)$. Finally, the virulence level for the $P$. syringae pv. syringae strains isolated from mango is heterogeneous and shows no correlation with any other distribution pattern, a situation similar to that previously described for $P$. syringae pv. syringae strains isolated from woody and herbaceous hosts (66). This heterogeneity was also observed for $P$. syringae pv. lachrymans isolates from cucumber leaves (58).

Interestingly, the different genetic and phenotypic approaches used in this work reveal that strain UMAF0005 could be wrongly classified as $P$. syringae pv. syringae. This strain could not be part of the $P$. syringae pv. syringae mango group, although it displays mangotoxin production. This suggests that it probably could belong to another pathovar of a $P$. syringae mangotoxin producer, as has been previously described (15).

Overall, our results based on the MLST and genetic and phenotypic diversity analysis strongly suggest that $P$. syringae pv. syringae strains isolated from mango constitute a differentiated phylotype that is specifically adapted to the mango host and distributed worldwide in the different subtropical areas where mango is grown and BAN is a relevant disease $(20,29)$. This phylotype associated with mango is separate from other phylogroups of pv. syringae isolated from others hosts and it is characterized mainly by the production of mangotoxin. Additionally, some genetic diversity techniques, such as rep-PCR, are useful in differentiating among strains of the differentiated phylotype isolated from various geographical areas, revealing their usefulness in epidemiological studies.

As mentioned above, the pathovar-based classification of the $P$. syringae-complex does not reveal the wide genetic diversity among pathovars previously observed in many studies $(8,22$, 49,63). The $P$. syringae complex shows a very heterogeneous genetic background, and an extensive revision of this group may be needed in the near future to better understand this group of phytopathogenic bacteria.

\section{ACKNOWLEDGMENTS}

This work has been supported by grants from CICE-Junta de Andalucía, Proyecto de Excelencia (P07-AGR-02471), and Plan Nacional de I+D+I del Ministerio de Ciencia e Innovación (AGL2011-30354-C02-01 and AGL2011-30343-C02-02) cofinanced by FEDER (EU). Plan Propio of the University of Málaga funded a stay by J. A. Gutiérrez-Barranquero at the Universidad Pública de Navarra, Spain and at the University of the West of England, Bristol, United Kingdom. We thank G. W. Sundin, A. Martín-Sanz, C. Caminero, A. Litchter, and A. Young for providing some $P$. syringae strains included in this study.

\section{LITERATURE CITED}

1. Alfano, J. R., and Collmer, A. 2004. Type III secretion system effector proteins: Double agents in bacterial disease and plant defense. Annu. Rev. Phytopathol. 42:385-414.

2. Arnold, D. L., Athey-Pollard, A., Gibbon, M. J., Taylor, J. D., and Vivian, A. 1996. Specific oligonucleotide primers for the identification of Pseudomonas syringae pv. pisi yield one of two possible DNA fragments by PCR amplification: Evidence for phylogenetic divergence. Physiol. Mol. Plant Pathol. 49:233-245. (Erratum: 1997, 51:213.)
3. Arrebola, E., Cazorla, F. M., Codina, J. C., Gutiérrez-Barranquero, J. A., Pérez-García, A., and de Vicente, A. 2009. Contribution of mangotoxin to the virulence and epiphytic fitness of Pseudomonas syringae pv. syringae. Int. Microbiol. 12:87-95.

4. Arrebola, E., Cazorla, F. M., Durán, V. E., Rivera, E., Olea, F., Codina, J. C., Pérez-García, A., and de Vicente, A. 2003. Mangotoxin: A novel antimetabolite toxin produced by Pseudomonas syringae inhibiting ornithine/ arginine biosynthesis. Physiol. Mol. Plant Pathol. 63:117-127.

5. Arrebola, E., Cazorla, F. M., Perez-García, A., and de Vicente, A. 2011. Chemical and metabolic aspects of antimetabolite toxins produced by Pseudomonas syringae pathovars. Toxins 3:1089-1110.

6. Arrebola, E., Cazorla, F. M., Romero, D., Pérez-García, A., and de Vicente, A. 2007. A nonribosomal peptide synthetase gene (mgoA) of Pseudomonas syringae pv. syringae is involved in mangotoxin biosynthesis and is required for full virulence. Mol. Plant-Microbe Interact. 20:500-509.

7. Baltrus, D. A, Nishimura, M. T., Dougherty, K. M., Biswas, S., Mukhtar, M. S., Vicente, J., Holub, E. B., and Dangl, J. L. 2012. The molecular basis of host specialization in bean pathovars of Pseudomonas syringae. Mol. Plant-Microbe Interact. 25:877-888.

8. Baltrus, D. A., Nishimura, M. T., Romanchuk, A., Chang, J. H., Mukhtar, M. S., Cherkis, K., Roach, J., Grant, S. R., Jones, C. D., and Dangl, J. L. 2011. Dynamic evolution of pathogenicity revealed by sequencing and comparative genomics of 19 Pseudomonas syringae isolates. PLoS Pathog. 7:e1002132.

9. Bender, C. L., Alarcón-Chaidez, F., and Gross, D. C. 1999. Pseudomonas syringae phytotoxins: Mode of action, regulation, and biosynthesis by peptide and polyketide synthetases. Microbiol. Mol. Biol. Rev. 63:266292.

10. Bender, C., and Cooksey, D. 1986. Indigenous plasmids in Pseudomonas syringae pv. tomato: Conjugative transfer and role in copper resistance. J. Bacteriol. 165:534-541.

11. Bereswill, S., Bugert, P., Völksch, B., Ullrich, M., Bender, C. L., and Geider, K. 1994. Identification and relatedness of coronatine-producing Pseudomonas syringae pathovars by PCR analysis and sequence determination of the amplification products. Appl. Environ. Microbiol. 60:2924-2930.

12. Block, A., and Alfano, J. R. 2011. Plant targets for Pseudomonas syringae type III effectors: Virulence targets or guarded decoys? Curr. Opin. Microbiol. 14:39-46.

13. Bradbury, J. F. 1986. Guide to Plant Pathogenic Bacteria, 1st ed. International Mycological Institute, Kew, UK.

14. Bull, C. T., Clarke, C. R., Cai, R., Vinatzer, B. A., Jardini, T. M., and Koike, S. T. 2011. Multilocus sequence typing of Pseudomonas syringae sensu lato confirms previously described genomospecies and permits rapid identification of $P$. syringae pv. coriandricola and $P$. syringae pv. apii causing bacterial leaf spot on parsley. Phytopathology 101:847-858.

15. Carrión, V. J., Gutiérrez-Barranquero, J. A, Arrebola, E., Bardaji, L., Codina, J. C., de Vicente, A., Cazorla, F. M., and Murillo, J. 2013. The mangotoxin biosynthetic operon ( $\mathrm{mbo}$ ) is specifically distributed within Pseudomonas syringae genomospecies 1 and has been acquired only once during evolution. Appl. Environ. Microbiol. 79:756-767.

16. Cazorla, F. M., Arrebola, E., Olea, F., Velasco, L., Hermoso, J. M., PérezGarcía, A., Torés, J. A., Farré, J. M., and de Vicente, A. 2006. Field evaluation of treatments for the control of the bacterial apical necrosis of mango (Mangifera indica) caused by Pseudomonas syringae pv. syringae. Eur. J. Plant Pathol. 116:279-288.

17. Cazorla, F. M., Arrebola, E., Sesma, A., Pérez-García, A., Codina, J. C., Murillo, J., and de Vicente, A. 2002. Copper resistance in Pseudomonas syringae strains isolated from mango is encoded mainly by plasmids. Phytopathology 92:909-916.

18. Cazorla, F. M., Codina, J. C., Abad, C., Arrebola, E., Torés, J. A, Murillo, J., Pérez-García, A., and de Vicente, A. 2008. 62-kb plasmids harboring rulAB homologues confer UV-tolerance and epiphytic fitness to Pseudomonas syringae pv. syringae mango isolates. Microbiol. Ecol. 56:283291.

19. Cazorla, F. M., Duckett, S. B., Bergström, E. T., Noreen, S., Odijk, R., Lugtenberg. B. J. J., Thomas-Oates, J., and Bloemberg, G. V. 2006. Biocontrol of avocado dematophora root rot by antagonistic Pseudomonas fluorescens PCL1606 correlates with the production of 2-hexyl 5-propyl resorcinol. Mol. Plant-Microbe Interact. 19:418-428.

20. Cazorla, F. M., Torés, J. A., Olalla, L., Pérez-García, A., Farré, J. M., and de Vicente, A. 1998. Bacterial apical necrosis of mango in Southern Spain: A disease caused by Pseudomonas syringae pv. syringae. Phytopathology 88:614-620.

21. Chapman, J. R., Taylor, R. K., Weir, B. S., Romberg, M. K., Vanneste, J. L., Luck, J., and Alexander, B. J. R. 2012. Phylogenetic relationships among global populations of Pseudomonas syringae pv. actinidae. Phytopathology 102:1034-1044.

22. Clerc, A., Manceau, C., and Nesme, X. 1998. Comparison of randomly 
amplified polymorphic DNA with amplified fragment length polymorphism to assess relatedness within genospecies III of Pseudomonas syringae. Appl. Environ. Microbiol. 64:1180-1187.

23. Cooksey, D. A. 1987. Characterization of a copper resistance plasmid conserved in copper-resistant strains of Pseudomonas syringae pv. tomato. Appl. Environ. Microbiol. 53:454-456.

24. Cuppels, D. A. 1986. Generation and characterization of $T n 5$ insertion mutations in Pseudomonas syringae pv. tomato. Appl. Environ. Microbiol. 51:323-327.

25. Ferrante, P., and Scortichini, M. 2010. Molecular and phenotypic features of Pseudomonas syringae pv. actinidiae isolated during recent epidemics of bacterial canker on yellow kiwifruit (Actinidia chinensis) in central Italy. Plant Pathol. 59:954-962.

26. Gardan, L., Shafik, H., Belouin, S., Broch, R., Grimont, F., and Grimont, P. A. D. 1999. DNA relatedness among the pathovars of Pseudomonas syringae and description of Pseudomonas tremae sp. nov. and Pseudomonas cannabina sp. nov. (ex Sutic and Dowson 1959). Int. J. Syst. Bacteriol. 49:469-478.

27. Gasson, M. J. 1980. Indicator technique for antimetabolic toxin production by phytopatogenic species of Pseudomonas. Appl. Environ. Microbiol. 39:25-29.

28. Gironde, S., and Manceau, C. 2012. Housekeeping gene sequencing and multilocus variable-number tandem-repeat analysis to identify subpopulations within Pseudomonas syringae pv. maculicola and Pseudomonas syringae pv. tomato that correlate with host specificity. Appl. Environ. Microbiol. 78:3266-3279.

29. Golzar, H., and Cother, E. 2008. First report of bacterial necrosis of mango caused by Pseudomonas syringae pv. syringae in Australia. Australas. Plant Dis. Notes 3:107-109.

30. Gutiérrez-Barranquero, J. A., Arrebola, E., Bonilla, N., Sarmiento, D., Cazorla, F. M., and de Vicente, A. 2012. Environmentally friendly treatment alternatives to Bordeaux mixture for controlling bacterial apical necrosis (BAN) of mango. Plant Pathol. 61:665-676.

31. Gutiérrez-Barranquero, J. A., Arrebola, E., Pérez-García, A., Codina, J. C., Murillo, J., de Vicente, A., and Cazorla, F. M. 2008. Evaluation of phenotypic and genetic techniques to analyze diversity of Pseudomonas syringae pv. syringae strains isolates from mango trees. Pages 271-281 in: Pseudomonas syringae Pathovars and Related Pathogens-Identification, Epidemiology and Genomics. M. B. Fatmi, A. Collmer, N. S. Iacobellis, J. W. Mansfield, J. Murillo, N. W. Schaad, and M. Ullrich, eds. Springer Netherlands, Dordrecht, The Netherlands.

32. Gutiérrez-Barranquero, J. A, de Vicente, A., Carrión, V. J., Sundin, G. W., and Cazorla, F. M. 2013. Recruitment and rearrangement of three different genetic determinants into a conjugative plasmid increase copper resistance in Pseudomonas syringae. Appl. Environ. Microbiol. 79:10281033.

33. Guttman, D. S., Vinatzer, B. A., Sarkar, S. F., Ranall, M., and Greenberg, J. T. 2002. A functional screen for the type III (Hrp) secretome of the plant pathogen Pseudomonas syringae. Science 295:1722-1726.

34. Güven, K., Jones, J. B., Momol, M. T., and Dickstein, E. R. 2004. Phenotypic and genetic diversity among Pseudomonas syringae pv. phaseolicola. J. Phytopathol. 152:658-666.

35. Hirano, S. S., Charkowski, A., Collmer, A., Willis, D. K., and Upper, C. D. 1999. Role of the Hrp type III protein secretion system in growth of Pseudomonas syringae B728a on host plant in the field. Proc. Natl. Acad. Sci. USA 96:9851-9856.

36. Hüttel, B., Winter, P., Weising, K., Choumane, W., Weigand, F., and Kahl, G. 1999. Sequence tagged microsatellite-site markers for chickpea (Cicer arietinum L.). Genome 42:210-217.

37. Hwang, M. S. H., Morgan, R. L., Sarkar, S. F., Wang, P. W., and Guttman, D. S. 2005. Phylogenetic characterization of virulence and resistance phenotypes of Pseudomonas syringae. Appl. Environ. Microbiol. 71: 5182-5191.

38. Jones, J. B., Chase, A. R., and Harris, G. K. 1993. Evaluation of the Biolog GN Microplate system for identification of some plant-pathogenic bacteria. Plant Dis. 77:553-558.

39. Kaluzna, M., Ferrante, P., Sobiczewski, P., and Scortichini, M. 2010. Characterization and genetic diversity of Pseudomonas syringae from stone fruits and hazelnut using repetitive-PCR and MLST. J. Plant Pathol. 92:781-787.

40. Kennelly, M. M., Cazorla, F. M., de Vicente, A., Ramos, C., and Sundin, G. W. 2007. Pseudomonas syringae diseases of fruit trees. Progress toward understanding and control. Plant Dis. 91:4-17.

41. King, E. O., Ward, M. K., and Raney, D. E. 1954. Two simple media for the demonstration of pyocyanin and fluorescin. J. Lab. Clin. Med. 44:301307.

42. Larkin, M. A., Blackshields, G., Brown, N. P., Chenna, R., McGettigan, P. A., McWilliam, H., Valentin, F., Wallace, I. M., Wilm, A., Lopez, R., Thompson, J. D., Gibson, T. J., and Higgins, D. G. 2007. Clustal W and Clustal X version 2.0. Bioinformatics 23:2947-2948.
43. Lim, C. K., and Cooksey, D. A. 1993. Characterization of chromosomal homologs of the plasmid-borne copper resistance operon of Pseudomonas syringae. J. Bacteriol. 175:4492-4498.

44. Lindeberg, M., Cunnac, S., and Collmer, A. 2012. Pseudomonas syringae type III effector repertoires: last words in endless arguments. Trends Microbiol. 20:199-208.

45. Little, E. L., Bostock, R. M., and Kirkpatrick, B. C. 1998. Genetic characterization of Pseudomonas syringae pv. syringae strains from stone fruits in California. Appl. Environ. Microbiol. 64:3818-3823.

46. Louws, F. J., Fullbright, D. W., Stephens, C. T., and de Brujin, F. J. 1994. Specific genomic fingerprints of phytopathogenic Xanthomonas and Pseudomonas pathovars and strains generated with repetitive sequences and PCR. Appl. Environ. Microbiol. 60:2286-2295.

47. Lydon, J., and Patterson, C. D. 2001. Detection of tabtoxin-producing strains of Pseudomonas syringae by PCR. Lett. Appl. Microbiol. 32:166170 .

48. Maiden, M. C., Bygraves, J. A., Feil, E., Morelli, G., Russell, J. E., Urwin, R., Zhang, Q., Zhou, J., Zurth, K., Caugant, D. A., Feavers, I. M., Achtman, M., and Spratt, B. G. 1998. Multilocus sequence typing: A portable approach to the identification of clones within populations of pathogenic microorganisms. Proc. Natl. Acad. Sci. USA 95:3140-3145

49. Manceau, C., and Horvais, A. 1997. Assessment of genetic diversity among strains of Pseudomonas syringae by PCR-restriction fragment length polymorphism analysis of rRNA operons with special emphasis on P. syringae pv. tomato. Appl. Environ. Microbiol. 63:498-505.

50. Martín-Sanz, A., Palomo, J. L., Pérez de la Vega, M., and Caminero, C. 2011. Identification of pathovars and races of Pseudomonas syringae, the main causal agent of bacterial disease in pea in North-Central Spain, and the search for disease resistance. Eur. J. Plant Pathol. 129:57-69.

51. Martín-Sanz, A., Pérez de la Vega, M., Murillo, J., and Caminero, C. 2012. Genetic, biochemical and pathogenic diversity of Pseudomonas syringae pv. pisi strains. Plant Pathol. 61:1063-1072.

52. Martín-Sanz, A., Pérez de la Vega, M., Murillo, J., and Caminero, C. 2013. Strains of Pseudomonas syringae pv. syringae from pea are phylogenetically and pathogenically diverse. Phytopathology 103:673681 .

53. McManus, P. S., and Jones, A. L. 1995. Genetic fingerprinting of Erwinia amylovora strains isolated from fruit tree crops and Rubus spp. Phytopathology 85:1547-1553.

54. Murillo, J., Bardaji, L., Navarro de la Fuente, L., Führer, M. E., Aguilera, S., and Alvarez-Morales, A. 2011. Variation in conservation of the cluster for biosynthesis of the phytotoxin phaseolotoxin in Pseudomonas syringae suggests at least two events of horizontal acquisition. Res. Microbiol. 162:253-261.

55. Murillo, J., and Keen, N. T. 1994. Two native plasmids of Pseudomonas syringae pathovar tomato strain PT23 share a large amount of repeated DNA, including replication sequences. Mol. Microbiol. 12:941-950.

56. Neu, H. C. 1992. The crisis in antibiotic resistance. Science 257:10641073.

57. Nürnberg, P., Roewer, L., Neitzel, H., Sperling, K., Pöpperl, A., Hundrieser, J., Pöche, H., Epplen, C., Zischler, H., and Epplen, J. T. 1989. DNA fingerprinting with the oligonucleotide probe $(\mathrm{CAC})_{5} /(\mathrm{GTG})_{5}$ : Somatic stability and germline mutations. Hum. Genet. 84:75-78.

58. Olczak-Woltman, H., Masny, A., Bartoszewski, G., Płucienniczak, A., and Niemirowicz-Szczytt, K. 2006. Genetic diversity of Pseudomonas syringae pv. lachrymans strains isolated from cucumber leaves collected in Poland. Plant Pathol. 56:373-382.

59. Pérez-García, A., Cánovas, F. M., Gallardo, F., Hirel, B., and de Vicente, A. 1995. Differential expression of glutamine synthetase isoforms in tomato detached leaflets infected with Pseudomonas syringae pv. tomato. Mol. Plant-Microbe Interact. 8:96-103.

60. Pérez-Martínez, I., Rodríguez-Moreno, L., Matas, I. M., and Ramos, C. 2007. Strain selection and improvement of gene transfer for genetic manipulation of Pseudomonas savastanoi isolated from olive knots. Res. Microbiol. 158:60-69.

61. Rademaker, J. L. W., Louws, F. J., and de Bruijn, F. J. 1998. Characterization of the diversity of ecologically important microbes by rep-PCR genomic fingerprinting. Pages 1-27 in: Molecular Microbial Ecology Manual. A. D. L. Akkermans, J. D. van Elsas, and F. J. de Bruijn, eds. Kluwer Academic Publishers, Dordrecht, The Netherlands.

62. Ribeiro, R. L. D., Hagedorn, D. J., Durbin, R. D., and Uchytil, T. F. 1979. Characterization of the bacterium inciting bean wildfire in Brazil. Phytopathology 69:208-212.

63. Sarkar, S. F., and Guttman, D. S. 2004. Evolution of the Core Genome of Pseudomonas syringae, a highly clonal, endemic plant pathogen. Appl. Environ. Microbiol. 70:1999-2012.

64. Sawada, H., Takeuchi, T., and Matsuda, I. 1997. Comparative analysis of Pseudomonas syringae pv. actinidiae and pv. phaseolicola based on phaseolotoxin-resistant ornithine carbamoyltransferase gene $(\operatorname{argK})$ and 
16S-23S rRNA intergenic spacer sequences. Appl. Environ. Microbiol. 63:282-288.

65. Schaad, N. W., Vidaver, A. K., Lacy, G. H., Rudolph, K., and Jones, J. B. 2000. Evaluation of proponed amended names of several Pseudomonads and Xanthomonads and recommendations. Phytopathology 90:208-213.

66. Scortichini, M., Marchesi, U., Dettori, M. T., and Rossi, M. P. 2003. Genetic diversity, presence of the $s y r B$ gene, host preference and virulence of Pseudomonas syringae pv. syringae strains from woody and herbaceous host plants. Plant Pathol. 52:277-286.

67. Sneath, P. H. A., and Sokal, R. P. 1973. Numerical taxonomy: The principles and practice of numerical classification. WH Freeman and Company, San Francisco.

68. Sundin, G. W., and Bender, C. L. 1993. Ecological and genetic analysis of copper and streptomycin resistance in Pseudomonas syringae pv. syringae. Appl. Environ. Microbiol. 59:1018-1024.

69. Sundin, G. W., Demezas, D. H., and Bender, C. L. 1994. Genetic and plasmid diversity within natural populations of Pseudomonas syringae with various exposures to copper and streptomycin bactericides. Appl. Environ. Microbiol. 60:4421-4431.

70. Tamura, K., Peterson, D., Peterson, N., Stecher, G., Nei, M., and Kumar, S. 2011. MEGA5: Molecular evolutionary genetics analysis using maximum likelihood, evolutionary distance, and maximum parsimony methods. Mol. Biol. Evol. 28:2731-2739.
71. Teverson, D. M. 1991. Genetics of pathogenicity and resistance in the halo-blight disease of beans in Africa. Ph.D. thesis, University of Birmingham, Birmingham, UK

72. Tourte, C., and Manceau, C. 1995. A strain of Pseudomonas syringae which does not belong to pathovar phaseolicola produces phaseolotoxin. Eur. J. Plant Pathol. 101:483-490.

73. Ullrich, M., Bereswill, S., Volksch, B., Fritsche, W., and Geider, K. 1993. Molecular characterization of field isolates of Pseudomonas syringae pv. glycinea differing in coronatine production. J. Gen. Microbiol. 139:19271937.

74. Versalovic, J., Schneider, M., deBruijn, F. J., and Lupski, J. R. 1994. Genomic fingerprinting of bacteria using repetitive sequence-based polymerase chain reaction. Methods Mol. Cell Biol. 5:25-40.

75. Völksch, B., and Weingart, H. 1998. Toxin production by pathovars of Pseudomonas syringae and their antagonistic activities against epiphytic microorganisms. J. Basic Microbiol. 38:135-145.

76. Young, A. 2008. Notes on Pseudomonas syringae pv. syringae bacterial necrosis of mango (Mangifera indica) in Australia. Australas. Plant Dis. Notes 3:138-140.

77. Young, J. M. 2010. Taxonomy of Pseudomonas syringae. J. Plant Pathol. 92:S1.5-S1-14.

78. Zhou, C., Yang, Y., and Jong, A. Y. 1990. Miniprep in ten minutes. BioTechniques 8:172-173. 